\title{
Spatio-temporal variability of micro-, nano- and pico- phytoplankton in the Mediterranean Sea from satellite ocean colour data of SeaWiFS
}

\author{
M. Sammartino ${ }^{1}$, A. Di Cicco ${ }^{1}$, S. Marullo ${ }^{2}$, and R. Santoleri ${ }^{1}$ \\ ${ }^{1}$ CNR - Istituto di Scienze dell'Atmosfera e del Clima, Rome, Italy \\ ${ }^{2}$ ENEA, Agenzia nazionale per le nuove tecnologie, l'energia e lo sviluppo economico sostenibile, \\ Centro Ricerche Frascati, Frascati, Italy
}

Correspondence to: M. Sammartino (michela.sammartino@artov.isac.cnr.it)

Received: 30 December 2014 - Published in Ocean Sci. Discuss.: 9 February 2015

Revised: 31 August 2015 - Accepted: 1 September 2015 - Published: 25 September 2015

\begin{abstract}
The seasonal and year-to-year variability of the phytoplankton size class (PSC) spatial distribution has been examined in the Mediterranean Sea by using the entire time series of Sea-viewing Wide Field-of-view Sensor (SeaWiFS) space observations (1998-2010). Daily maps of PSCs have been determined using an empirical model based on a synoptic relationship between surface chlorophyll $a$ and diagnostic pigments referred to different taxonomic groups. The analysis of micro-, nano- and pico-phytoplankton satellite time series (1998-2010) describes, quantitatively, the algal assemblage structure over the basin and reveals that the main contribution to chlorophyll $a$ in most of the Mediterranean Sea comes from the pico-phytoplankton component, especially in nutrient-poor environments. Regions with different and peculiar features are the Northwestern Mediterranean Sea, the Alborán Sea and several coastal areas, such as the North Adriatic Sea. In these areas, local interactions between physical and biological components modulate the composition of the three phytoplankton size classes. It results that, during the spring bloom season, micro-phytoplankton dominates in areas of intense vertical winter mixing and deep/intermediate water formation, while in coastal areas micro-phytoplankton dominates in all seasons because of the nutrient supply from the terrestrial inputs. In the Alborán Sea, where the Atlantic inflow modulates the nutrient availability, any predominance of one class over the other two has been observed. The nanophytoplankton component instead remains widespread over the entire basin along the year, and its contribution to chlorophyll $a$ is of the order of 30-40\%. The largest inter-annual signal occurs in the Northwestern Mediterranean Sea, driven
\end{abstract}

by the year-to-year variation in intensity and extension of the spring bloom, followed by the Alborán Sea, in which the inter-annual variability is strongly modulated by the Atlantic inflow.

In absence of sufficient in situ data of community composition, the satellite-based analysis demonstrated that pico-, nano- and micro-phytoplankton classes often coexist. The predominance of one group over the other ones is strongly dependent on the physical and biological processes occurring at the mesoscale. These processes directly influence the nutrient and light availability, which are the principal forcing for the algae growth.

\section{Introduction}

Phytoplankton represents an important element for the survival and comprehension of the marine ecosystem. Its scientific importance is owing to its ecological role in the global carbon cycle and greenhouse effect (Park et al., 2015). Phytoplankton plays a key role in the biological carbon pump not only for its consumption of inorganic carbon during photosynthesis but also for the transport of organic carbon from the surface to deep layers of ocean. Moreover, phytoplankton contributes to the primary production, due to its rapid turnover and to the great extension of the ocean on Earth's surface (Falkowski et al., 1998).

The biogeographic distribution of phytoplankton biomass, on global and regional scales, is directly influenced by bi- 
ological, chemical and physical factors such as light, nutrient availability, presence of competitors, predators, as well as temperature and $\mathrm{pH}$, which are all connected to the local dynamics of water masses. These biotic and abiotic factors create a complex system in which the phytoplankton, in being a primary producer, plays a relevant role (Reynolds, 1989) and represents the first step of the ecological pyramid as well as the food web (Klauschies et al., 2012).

The availability of light and nutrients strongly influences the phytoplankton biomass and community structure; when nutrients are reduced, the smaller component of algal biomass predominates on the bigger one, but when the system shifts to the inverse biogeochemical condition, the community tends to change its structure, being predominated by large cells. These types of changes could have a strong impact on the marine system and on the stoichiometry, carbon storage and biogeochemistry (Marinov et al., 2010).

Any change of the marine ecosystem state is also reflected in new morphological and physiological adjustments, just like the change of size for each specific trophic level (Thingstad and Rassoulzadegan, 1999).

Thanks to the relationship between dimensions and pigmentary content, different taxa or stages of growth in the same taxon, photosynthetic efficiency and bio-optical phytoplankton properties (Chisholm, 1992; Organelli et al., 2007; Raven, 1998), "cell size" becomes an important descriptor of the community structure. Indeed, phytoplankton cell size and pigment content are some of the physiological traits that influence the rate of acquiring and processing energy and materials from the environment (Brown et al., 2004). The size and biodiversity of the phytoplankton community can modulate the amount of carbon fixed and exported into the deep sea with respect to the nutrient availability (Finkel et al., 2010).

A shift in the phytoplankton size structure from a dominance of picoplankton to predominance of larger nano- and micro-phytoplankton is associated with a shift in the pelagic food web (Finkel et al., 2010). The dimension of cells and consequently the structure of the algal community can influence the trophic organization of the marine ecosystem and the ability to produce more organic matter to be transferred across the successive trophic stages (Marañòn et al., 2012).

Given the importance of cell size in understanding the relationship between phytoplankton assemblage and marine ecosystem dynamics, it is common to classify the algal community in micro-, nano- and pico-phytoplankton. One of the most common definitions for phytoplankton size classes (PSCs) identifies the size ranges of the phytoplankton cells as follows: micro-phytoplankton: $>20 \mu \mathrm{m}$, nanophytoplankton: from 2 to $20 \mu \mathrm{m}$, and pico-phytoplankton: $<2 \mu \mathrm{m}$ (Sieburth et al., 1978). In oligotrophic waters the pico-phytoplankton provides a relevant contribution to the total content of chlorophyll $a$ (Agawin et al., 2000), the latter defined as the sum of chlorophyll $a$, its allomers and epimers, divinyl chlorophyll $a$, chlorophyllide $a$ (Hooker et al., 2005) and called TChl $a$ or chlorophyll $a$ hereafter. However, in eu- trophic water where cells have the opportunity to grow due to the availability of nutrients and light, the larger cells prevail (Irwin et al., 2006).

In terms of biogeochemical function and role, the size structure of phytoplankton communities provides important information such as the knowledge of the community composition itself (Vidussi et al., 2001; Chisholm, 1992; Raven, 1998). Indeed, in some cases, several biogeochemical functions correspond to a particular taxon or size class; for instance, cyanobacteria often represent a large group of picophytoplanktonic nitrogen fixers. They are able to fix and use the forms of atmospheric nitrogen, thereby having a direct impact on climate change. Yet, the principal components of the micro-phytoplankton, diatoms and dinoflagellates play a dominant role in the carbon flux into deeper waters (Nair et al., 2008; Sathyendranath, 2014). In these cases a PFT (phytoplankton functional type) classification is adopted, in which each type defines a group of different species with a common ecological function.

Information about the composition of phytoplankton community structure can be obtained from the analysis of in situ samples using different laboratory techniques such as flow cytometry, which provides information about the number and the dimensions of the fluorescent cells in a specific water sample volume; HPLC (high pressure liquid chromatography), which is used to retrieve the composition and concentration of the pigment contents of the cells; spectrophotometry, which provides the pigment light absorption in the visible spectrum and filtration of water through filter pads of a known size together with in vitro fluorometric chlorophyll $a$ extraction. As a result, considerable data on in situ dimensional classes measures exist, which could also be useful for other applications like calibration and validation of satellite PSC algorithms.

From space, the composition of the community is detected by exploiting the signature of the different species and classes on the optical properties in the water column. Light absorption of a cell is affected by its pigment "package effect" (Morel and Bricaud, 1981; Bricaud et al., 2004) which, in describing the chlorophyll $a$ efficiency in the light harvesting, is a direct function of the pigment cellular concentration and therefore of the "cell size" (Chisholm, 1992; Raven, 1998; Basset et al., 2009).

Concentration of chlorophyll $a$, light absorption and backscattering signals, derived from remote-sensing reflectance, are the main ocean colour variables that provide synoptic and multi temporal information about phytoplankton distribution. Several satellite models have been developed in recent years to classify the algal cells on the basis of optical variable measured from space. These are usually divided into two main classes: direct models, which exploit the optical properties directly captured by the sensor; and indirect models, as those based on the strong relationship between the chlorophyll $a$ concentration and the functional groups or taxa and PSCs (Moisan et al., 2012). 
Another classification of these methods is based on the spectral-response and abundance-based approaches (Brewin et al., 2011a). The spectral-response models analyse the differences in the shape of the light reflectance/absorption spectrum to provide information about different phytoplankton classes; an example of this model is the Alvain et al. (2005, 2008) one, in which different phytoplankton groups are identified from the normalized water-leaving radiance data. These authors exploit the anomalies in the spectral signature of a specific taxon or a specific type of community after removing the chlorophyll $a$ signal from the radiance measure. The abundance-based models, instead, exploit the information coming from the magnitude of chlorophyll $a$ biomass or light absorption to separate one group from another (Devred et al., 2006; Uitz et al., 2006; Hirata et al., 2008, 2011; Brewin et al., 2010, 2011b). Most of the satellite PSC models are based on a specific variable, e.g. the absorption coefficient at different wavelength of the cells (Sathyendranath et al., 2001) or the particle backscattering coefficient (Kostadinov et al., 2009). Others are mixed models, just as in the case of Fujiwara et al. (2011), in which the algorithm partitions between the pico- + nano-phytoplankton community and the micro-phytoplankton community, involving the absorption and backscattering coefficients.

Most of the models described above were developed for the global ocean and applied to infer phytoplankton composition or classes from space allowing for the study of their seasonal and inter-annual variability at global scales (Brewin et al., 2010, 2011b; Hirata et al., 2008, 2011; Uitz et al., 2006; Mouw and Youder, 2010). In this paper, instead, we used a chlorophyll- $a$-based model to estimate phytoplankton composition in the Mediterranean Sea with the aim of studying the spatial and temporal variability of phytoplankton assemblage dynamics. The choice to test a chlorophyll$a$-based model rather than spectrally based ones was inspired by the possibility to check the global model performance at regional scale by using available in situ observations. Indeed, in Mediterranean Sea, the in situ data related to diagnostic pigments (sum of seven marker pigments intended as size taxonomic pigments, DP; Vidussi et al., 2001) is much greater than the optical measurements, which are very limited and not always freely available.

Presently, chlorophyll $a$ estimates from ocean colour data were widely used to study the Mediterranean phytoplankton biomass variability at basin and sub-basin scales (e.g. Antoine and Morel, 1996, Antione et al., 1996; Santoleri et al., 2003; Bosc et al., 2004; Volpe et al., 2012b). Only recently, Navarro et al. (2014), adapted the PHYSAT method of Alvain et al. (2005) to the Mediterranean Basin's biooptical characteristics, thereby providing a regional algorithm to estimate dominant phytoplankton groups (nanoeukaryotes, Prochlorococcus, Synechococcus, diatoms and coccolithophores) from MODIS (Moderate Resolution Imaging Spectroradiometer) water leaving radiance measures.
Therefore, the objective of this work is dual: (i) to understand how well a simple empirical model solely based on chlorophyll $a$ data, as per Brewin et al. (2011b) hereafter referred to as BR, can describe the phytoplankton biomass distribution in the Mediterranean Sea; and (ii) to study the spatio-temporal variability of the three phytoplankton size classes (micro-, nano- and pico-phytoplankton) in this basin, by applying the selected model to the ocean colour products. This paper will be the first attempt to describe the seasonal and inter-annual evolution of the phytoplankton size classes assemblage during the entire SeaWiFS (Sea-viewing Wide Field-of-view Sensor) era. In Sect. 2, we present the satellite and in situ data we used. In the same section we briefly describe the selected PSC model. In Sect. 3 we describe the BR model validation over the Mediterranean Sea, using HPLC observations. Finally, the variability and distribution of PSCs are analysed at different scales of time and space (Sects. 4 6). Conclusions (Sect. 7) summarize the results and present future perspectives.

\section{The study area}

The Mediterranean Sea (Fig. 1), although relatively small, is characterized by a circulation that can be compared to that of a large-scale ocean. It is the most interesting of the semienclosed seas because of the great range of processes and interactions that occur within it (Robinson and Golnaraghi, 1994). Most of the physical and biological processes that characterize the global ocean, many of which are not well known or understood, occur analogously in the Mediterranean Sea (Siokou-Frangou et al., 2010; Lacombe et al., 1981; Robinson and Golnaraghi, 1994). These biological and physical processes interact with each other and influence, directly, the distribution of the phytoplankton and zooplankton communities and the optical properties of the seawater. Unlike the other seas and oceans, the Mediterranean Sea has unique optical properties in the water column, with "oligotrophic waters less blue $(30 \%)$ and greener $(15 \%)$ than the global ocean" (Volpe et al., 2007). Many hypotheses were developed in the past to understand and justify the reason why the Mediterranean Sea shows these properties. One of them is relative to the high yellow substance content, which can be responsible for the enhancement of absorbing material (Claustre and Maritorena, 2003; Morel and Gentili, 2009). Another hypothesis attributes this effect to the presence of coccoliths (D’Ortenzio et al., 2002; Gitelson et al., 1996), while a third hypothesis is related to the presence of submicron Saharan dust in suspension in the surface layer (Claustre et al., 2002). Finally, Volpe et al. (2007) suggest that the different phytoplankton community structure, typical of the basin, could alter the spectral signature and therefore be responsible for the peculiar colour of the Mediterranean Sea. Nowadays, an unequivocal factor which can optimally justify the Mediterranean being "greener" than other oceans does not exist. Therefore, this peculiarity has made it necessary to 


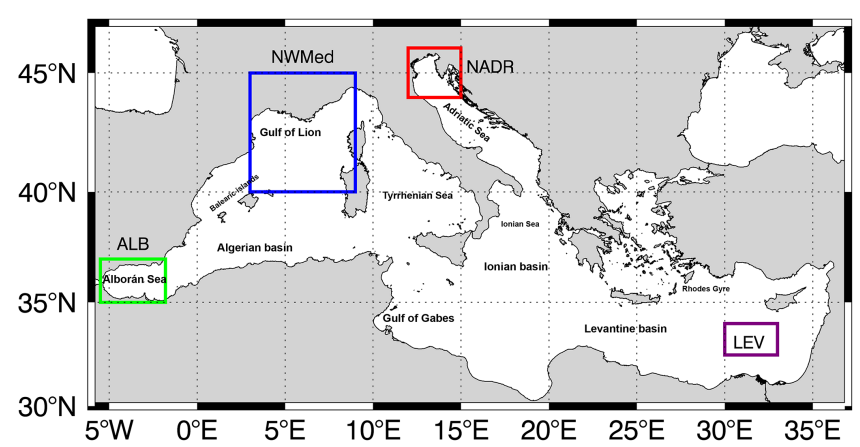

Figure 1. Maps of the Mediterranean Sea and its most interesting basins or sub-basins. The box indicates the region analysed in Sect. 6 for the seasonal and inter-annual variability of TChl $a$ and PSCs at local scales. The green box refers to the Alborán Sea (ALB), the blue box to the Northwestern Mediterranean Sea (NWMed), the red one indicates the North Adriatic Sea (NADR) and the purple box refers to the Levantine Sea (LEV).

develop regional bio-optical algorithms in order to estimate chlorophyll $a$ concentrations from in situ optical measurements and satellite data (D'Ortenzio et al., 2002; Volpe et al., 2007; Santoleri et al., 2008). Finally, the optical properties of the Mediterranean Sea suggest verifying whether a PSC model designed for global ocean applications can perform similarly in the Mediterranean Sea.

\section{Data and methods}

\subsection{Satellite data and processing}

The satellite data used in this work comes from SeaWiFS. They are daily chlorophyll $a$ Level 3 (L3) data (resolution $1.1 \mathrm{~km}$ ), from 1998 to 2010, produced by the research group of Global Ocean Satellite (GOS) monitoring and marine ecosystem studies of the Institute of Atmospheric Sciences and Climate (ISAC) of the Italian National Research Council (CNR) and made available to the scientific community. We used the so-called Mediterranean Case1- and Case2merged chlorophyll $a$ product (GOS Chl_1-2). These daily chlorophyll $a$ fields are derived from L1 SeaWiFS passes applying two different bio-optical regional algorithms for open and coastal waters (see Volpe et al., 2012a, for the details of processing). The MedOC4 (Mediterranean ocean colour four-bands ) algorithm is used to retrieve chlorophyll $a$ in the Case 1 waters (Volpe et al., 2007) while the Ad4 is applied for the Case 2 waters (D'Alimonte and Zibordi, 2003). The identification of the optical properties of each pixel is based on the D'Alimonte method (D'Alimonte et al., 2003), which takes into account the entire spectrum from the blue band to NIR (near infrared), for both Case 1 and Case 2 waters types. For intermediate waters, a weighted average of the two algorithms based on the distance between the actual reflectance spectra and the reference one for the Case 1 and 2 waters is applied.

The choice of applying an algorithm made specifically for the Mediterranean Case 1 waters, as MedOC4, provides a more realistic value of TChl $a$, as demonstrated by Volpe et al. (2007), who showed that NASA SeaWiFS chlorophyll $a$ fields are affected by an uncertainty of the order of $100 \%$ (Volpe et al., 2007) and has been confirmed by several authors. The MedOC4 algorithm was developed from a readjustment of the NASA algorithm OC4 (ocean chlorophyll 4; O'Reilly et al., 1998), in which the coefficients were obtained from a fourth power polynomial regression fit between logtransformed in situ Mediterranean chlorophyll $a$ concentration and maximum band ratios at a specific wavelength obtained by in situ optical profiles (Volpe et al., 2007). Similarly, the Ad4 has been tuned by using the bio-optical data set acquired by JRC (Joint Research Center) in the Venice Tower located in the North Adriatic Sea.

Besides the use of a regional algorithm, all the data distributed by GOS and those distributed by MyOcean OCTAC (Ocean Colour Thematic Assembly Centre) to the end-users are quality checked. The daily TChl $a$ fields, used as input in this work, were subjected to quality assessment through classical matchup analysis (called offline validation in Volpe et al., 2012a). Volpe et al. (2012a) demonstrate that the SeaWiFS Mediterranean regional products match up well to the corresponding in situ data showing the following statistical results: the correlation coefficient $\left(r^{2}\right) 0.815$, root mean square (RMS) $0.253 \mathrm{mg} \mathrm{m}^{-3}$, bias $-0.019 \mathrm{mg} \mathrm{m}^{-3}$, relative (RPD) and absolute (APD) percentage differences, 15 and $51 \%$, respectively (see Table 4 in Volpe et al., 2012a). Given the log-normal chlorophyll $a$ distribution, $r^{2}$, RMS and bias are calculated over log-transformed quantities, while RPD and APD are calculated over untransformed pairs of values.

Here, daily chlorophyll $a$ maps, at $4 \mathrm{~km}$ of resolution, were used to compute monthly maps covering the SeaWiFS era (1998-2010), then the monthly means were averaged to compute monthly climatology. Moreover, TChl $a$ fields at monthly and climatological scales were then used to support the analysis of phytoplankton biomass variability. In these maps, the chlorophyll $a$ concentration is expressed as base log-10 transformed considering the log-normal distribution of this pigment.

The BR method was then applied to compute the PSCs daily fields over the Mediterranean Sea for the entire SeaWiFS time series. This model expresses the TChl $a$ concentration as the sum of the pico-, nano- and micro-phytoplankton chlorophyll $a$ fraction, and each class is computed by using a simple function of the chlorophyll $a$. For more details about the algorithm, see Brewin et al. (2011b). The daily PSCs fields are then used to produce monthly climatological fields. 


\subsection{In situ data and processing}

The in situ data set used in this paper is the SeaBASS (SeaWiFS Bio-optical Archive and Storage System) HPLC-based diagnostic pigments data set (Werdell and Bailey, 2005). All the data acquired in the Mediterranean Sea were extracted from this global data set and used for model validation purposes. The Mediterranean SeaBASS data set (referred to as "MED in situ", hereafter) consists of 1454 samples acquired in the basin since 1999 and represents the $15 \%$ of the global SeaBASS data. The MED in situ data were acquired during two trans-Mediterranean cruises (Prosope99, and Boum08) covering the basin from Gibraltar to the eastern Mediterranean, and near the BOUSSOLE mooring where periodic measurements were carried out from 2001 to 2006. The details of the in situ observation in terms of location, period of sampling, TChl $a$ value ranges and sampling depth are reported in Table 1. Even if most of the data were acquired at the BOUSSOLE sampling site, the measurements still cover the entire range values of the Mediterranean chlorophyll $a$ variability, with values ranging from less than 0.05 to more than $5 \mathrm{mg} \mathrm{m}^{-3}$.

The MED in situ pigment data set was quality checked and filtered by applying the same procedure used by Brewin et al. (2011b). Following Aiken et al. (2009), outliers were determined from the regression of accessory pigments against TChl $a$ excluding values behind the $95 \%$ confidence interval of the regression. This reduces the number of samples from 1454 to 1085 .

This data set was then used to compute the in situ quantification of PSCs following the methods described in Brewin et al. (2011b), based on the previous works of Vidussi et al. (2001) and Uitz et al. (2006).

We point out that the NOMAD (NASA bio-Optical Marine Algorithm Data) data set used by Brewin et al. (2011b) to develop their PSC model, after filtering, does not include any Mediterranean data points; therefore, our Mediterranean data set can be considered fully independent.

\section{Brewin model performances over the Mediterranean Sea}

The MED in situ is used to evaluate, for the first time, the BR model accuracy over the Mediterranean Sea (Table 2, Fig. 2). Figure 2a-c show the micro-, nano- and picophytoplankton fractions obtained by applying the Uitz et al. (2006) DP coefficients, as a function of TChl $a$. A rather large scatter of the data around the model curves suggests that, in the real world, the relative abundance of micro-, nano- and pico-phytoplankton cannot be a simple function of the chlorophyll $a$ concentration alone. In particular, the BR model strongly underestimates the nano-phytoplankton fraction measured in the Mediterranean Basin in the entire range of TChl $a$ values, while it overestimates the pico-
Uitz et al. (2006) coefficients

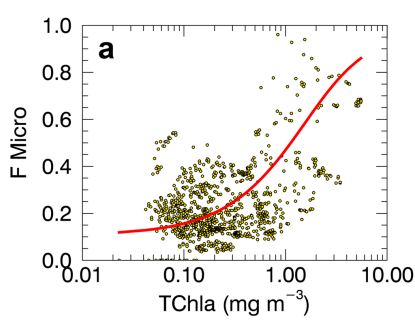

Di Cicco (2014) coefficients
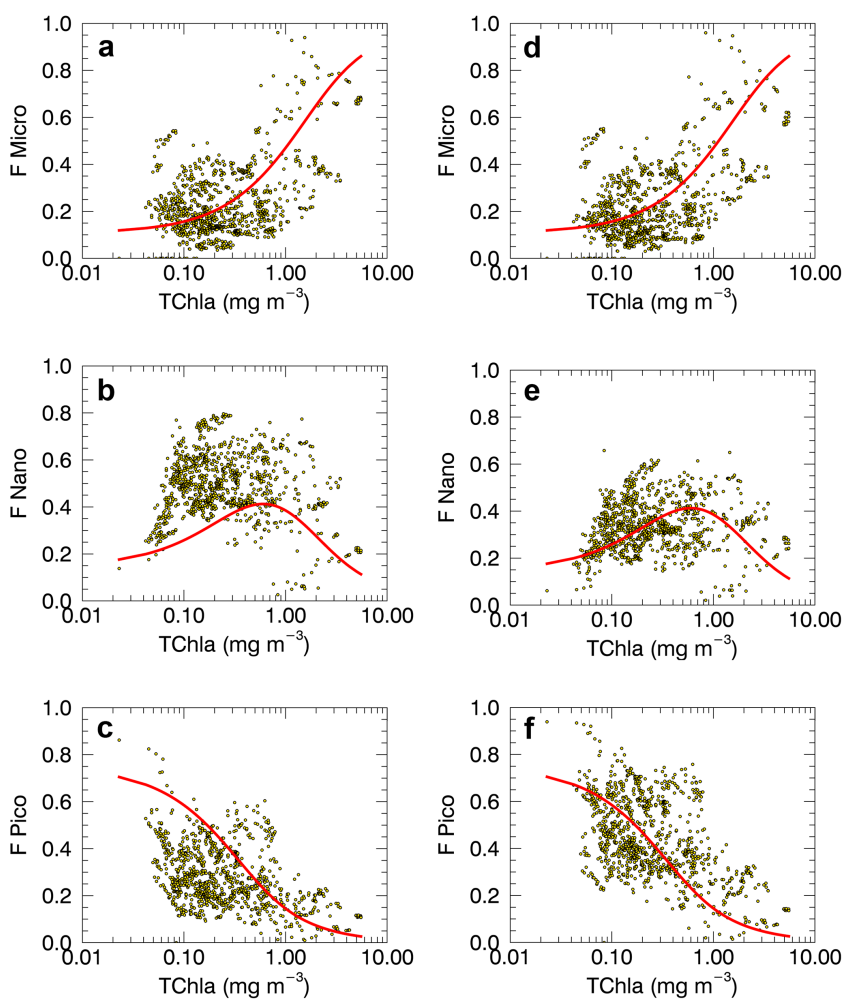

Figure 2. BR model (red line) plotted against in situ PSC classification (yellow dots) obtained using the Uitz et al. (2006) coefficients (a-c, on the left panel) and Di Cicco (2014) coefficients (d-f, on the right panel). The yellow dots refer to the in situ size class fractions resulting from the use of the diagnostic pigments (DP) of the SeaBASS Mediterranean subset.

phytoplankton fraction for TChl $a$ concentrations of less than $0.8 \mathrm{mg} \mathrm{m}^{-3}$; only for micro-phytoplankton does the curve fall in middle of the observed cloud of data points. These results are quantitatively confirmed by the statistical analysis, which shows a $\log 10$ bias error of $-4,-26$ and $67 \%$ for micro-, pico- and nano-phytoplankton fractions, respectively.

The poor performance of the model can be due to the particular optical properties of Mediterranean waters, which makes this basin unique with respect to the other oceans (see Sect. 1). For this reason, before performing any new adjustment to the BR coefficients, we first investigate whether a different relation between DP and chlorophyll $a$ in the Mediterranean basin can be responsible for the observed biases. This allows us also to verify the Volpe et al. (2007) hypothesis, which considers the different assemblage of the phytoplankton community structure as one of the possible causes responsible for the greener colour of the Mediterranean Sea. Recently, Di Cicco (2014) provided a regional DP and chlorophyll $a$ relationship, which is entirely based on Mediterranean data. Di Cicco, by applying the Gieskes et al. (1988) approach to the MED in situ data, performed a new 
Table 1. Information about the in situ SeaBASS sub-data set used for validating of the application of the BR model on the Mediterranean Sea.

\begin{tabular}{|c|c|c|c|c|c|c|}
\hline Cruise & Date & Location & No. samples & Depth (m) & $\begin{array}{r}\text { TChl } a \text { range } \\
\text { values }\left(\mathrm{mg} \mathrm{m}^{-3}\right)\end{array}$ & Sources \\
\hline Prosope 99 & 14/09/1999-03/10/1999 & Trans-Mediterranean & 255 & $0-50$ & $0.02-0.89$ & SeaBASS \\
\hline BOUSSOLE Mooring & 22/07/2001-03/12/2006 & $\begin{array}{l}\text { Northwestern } \\
\text { Mediterranean Sea }\end{array}$ & 1143 & $0-50$ & $0.02-5.52$ & SeaBASS \\
\hline Boum08 & 03/07/2008-18/07/2008 & Trans-Mediterranean & 33 & 9 & $0.03-0.15$ & SeaBASS \\
\hline BOUSSOLE03 & 15/07/2008-19/07/2008 & $\begin{array}{l}\text { Northwestern } \\
\text { Mediterranean Sea }\end{array}$ & 23 & $0-50$ & $0.08-2.20$ & SeaBASS \\
\hline
\end{tabular}

multiple regression analysis to evaluate whether different pigment ratios of the phytoplankton community can occur in the basin and showed that the use of the Uitz DP-TChl $a$ relationship results in an underestimation of the Mediterranean TChl $a$ estimate over all its range values; namely, the Uitz line fit has a slope coefficient of less than 1. The new MED DP-TChl $a$ relationship found by Di Cicco (2014) is

$$
\begin{aligned}
\text { TChl } a^{*} & =1.999[\text { Zea }]+1.624[\text { TChl } b]+2.088[\text { Allo }] \\
& +0.861\left[19^{\prime} \text { Hex }- \text { fuco }\right]+0.405\left[19^{\prime} \text { But }- \text { Fuco }\right] \\
& +1.74[\text { Fuco }]+1.172[\text { Peri }]
\end{aligned}
$$

in which each PSC fraction is computed as follows:

$$
\begin{aligned}
& f_{\text {pico }}= \\
& \left\{\begin{array}{l}
\frac{(-12.5 \mathrm{TChl} a+1) 0.861\left[19^{\prime} \mathrm{Hex}-\text { fuco }\right]+1.999[\mathrm{Zea}]+1.624[\mathrm{TChl} b]}{\mathrm{TChl} a^{*}} \\
\text { if TChl } a<0.08 \mathrm{mg} \mathrm{m}{ }^{3} \\
\frac{1.999[Z e a]+1.624[\mathrm{TChl} b]}{\text { TChl } a^{*}} \\
\text { if TChl } a>0.08 \mathrm{mg} \mathrm{m}{ }^{3}
\end{array}\right. \\
& f_{\text {nano }}= \\
& \left\{\begin{array}{l}
\frac{(12.5 \mathrm{TChl} a) 0.861\left[19^{\prime} \mathrm{Hex}-\text { fuco }\right]+\left(0.405\left[19^{\prime} \mathrm{But}-\text { fuco }\right)+2.088[\mathrm{Allo}]\right)}{\mathrm{TChl}^{*} a^{*}} \\
\frac{\left(2.088[\mathrm{Allo}]+0.861\left[19^{\prime} \mathrm{Hex}-\text { fuco }\right]+0.405\left[19^{\prime} \mathrm{But}-\text { fuco }\right)\right.}{\mathrm{TChl} a^{*}} \\
\text { if TChl } a>0.08 \mathrm{mg} \mathrm{m}^{3},
\end{array}\right.
\end{aligned}
$$

$$
f_{\text {micro }}=\frac{1.74[\text { Fuco }]+1.172[\text { Peri }]}{\text { TChl } a^{*}}
$$

where TChl $a$ is the in situ total chlorophyll $a$ concentration and TChl $a^{*}$ is the estimated one. For more details about the new coefficient retrieval, see Di Cicco (2014).

Consequently, we applied the new Di Cicco (2014) coefficients to obtain the new in situ PSC classification to be compared with the BR model. Effectively, the improved performance of the model with respect to the in situ PSC fractions (shown in Fig. 2d-f) highlights how important the relation between the diagnostic pigments and TChl $a$ content is. Figure 2 summarizes the comparison between the BR satellite model and the in situ PSC fractions as obtained by using, respectively, the Uitz et al. (2006) (Fig. 2a-c) and Di Cicco (2014) DP coefficients (Fig. 2d-f), while the statistical results are shown in Table 2. Figure 2 shows that the in situ Uitz PSC classification is not suitable for the Mediterranean Sea and a regional classification is therefore necessary. This is evident, in particular, for the nano-phytoplankton case (Fig. 2e), in which the use of the MED DP relationship shifts down the cloud points and results in a better performance of the BR model with the $\log 10 \%$ mean bias error falling from 67 to only $8 \%$. By observing the pico-phytoplankton scatter plot (Fig. 2f), the dots are now distributed around the model curve for the entire range of chlorophyll $a$ values, and the percentage of $\log 10$ bias decreases from -26 to $14 \%$. The micro-phytoplankton component represents a similar behaviour, both applying the global coefficients and the Mediterranean ones, as confirmed by the statistical results. The statistic in Table 2, computed both in linear scale and in log-transformed scale using the reference equations of Table 3 confirms that the use of Di Cicco DP relationship is a key factor to improving the in situ PSC classification. When Eq. (1) is used, the errors we found applying the BR model result in a $\mathrm{MBE} \%$ range from -4 to $21 \%$, which is of the same order that is found by Brewin et al. (2010) by using an independent data set (from 11 to $13.3 \%$ ). Consequently, we conclude that an adaptation of the BR model coefficients for the Mediterranean case is not a priority considering the limited margin for improvement left after the tuning of the Uitz DP-TChl $a$ coefficients.

\section{Seasonal variability of spatial distribution of the PSCs in the Mediterranean Sea}

The seasonal evolution of the chlorophyll $a$ distribution in the Mediterranean Sea is driven by the life cycle of the phytoplanktonic organisms, which follows the typical succession of temperate areas with a high biomass increase in late winter/early spring, a decrease in summertime and a second smaller bloom in autumn. PSC variability follows this oscillation mostly driven by the evolution of the chlorophyll $a$ concentration and its west to east gradient (see Fig. $1 \mathrm{Sa}-\mathrm{c}$ in the Supplement). This spatial gradient is one of the domi- 
Table 2. Statistical results from the comparison of the BR model and in situ PSC classification obtained using, in the diagnostic pigments analysis, respectively the Uitz et al. (2006) and the Di Cicco (2014) coefficients. Mean bias error (MBE) has the same dimensions of in situ observations ( $x$ in Table 3), while mean bias error percentages (MBE \%), root mean square error percentages (RMSE \%) and linear Pearson correlation coefficients $(r)$ are dimensionless and refer to a TChl $a$ smoothed with a 5-point running mean. Where "_log10" refers to log-transformed units, otherwise it is expressed in linear space.

\begin{tabular}{lrrrrr}
\hline \multicolumn{7}{c}{ Uitz et al. (2006) coefficients } & & \\
\hline & MBE $\left(\mathrm{mg} \mathrm{m}^{-3}\right)$ & MBE \% & MBE \%_log10 & RMSE \%_log10 & r_log10 \\
\cline { 2 - 6 } Micro-phytoplankton & 0.059 & $14 \%$ & $-4 \%$ & $29 \%$ & 0.6 \\
Nano-phytoplankton & -0.060 & $-34 \%$ & $67 \%$ & $79 \%$ & 0.5 \\
Pico-phytoplankton & -0.002 & $51 \%$ & $-26 \%$ & $42 \%$ & 0.7 \\
\hline & \multicolumn{1}{c}{ Di Cicco (2014) coefficients } & & \\
\hline & MBE (mg m $\left.{ }^{-3}\right)$ & MBE \% & MBE \%_log10 & RMSE \%_log10 & r_log10 \\
\cline { 2 - 6 } Micro-phytoplankton & 0.066 & $21 \%$ & $-7 \%$ & $28 \%$ & 0.6 \\
Nano-phytoplankton & -0.016 & $-4 \%$ & $8 \%$ & $22 \%$ & 0.5 \\
Pico-phytoplankton & -0.050 & $-7 \%$ & $14 \%$ & $46 \%$ & 0.8 \\
\hline
\end{tabular}

Table 3. Basic statistical quantities used for the assessment of the comparison of the BR model applied on the Mediterranean Sea, using the two different in situ PSC classification approaches (Uitz et al., 2006, and Di Cicco, 2014, coefficients). $N$ is the number of observations and $x$ is in situ measure.

\begin{tabular}{ll}
\hline $\begin{array}{l}\text { Percent mean } \\
\text { bias error }\end{array}$ & MBE\% $=\frac{1}{N} \sum_{i=1}^{N}\left(\frac{\text { Model }-x_{i}}{x_{i}}\right) \times 100$ \\
$\begin{array}{l}\text { Percent root mean } \\
\text { squared error }\end{array}$ & RMSE\% $=\sqrt{\frac{1}{N} \sum_{i=1}^{N}\left(\frac{\text { Model }-x_{i}}{x_{i}}\right)^{2}} \times 100$ \\
$\begin{array}{l}\text { Pearson correlation } \\
\text { coefficient }\end{array}$ & $r=\frac{\sum_{i}\left(\text { model }_{i}-{\text { model })\left(x_{i}-\bar{x}\right)}^{\sum_{i}\left(\text { model }_{i}-\text { model }^{2} \sqrt{\sum_{i}\left(x_{i}-x\right)^{2}}\right.}\right.}{\text { Mean bias error }}$ \\
\hline
\end{tabular}

nant features of the chlorophyll $a$ distribution in the Mediterranean Sea and reinforces the paradigm of an extremely oligotrophic eastern basin and a more productive western side (D'Ortenzio and Ribera d'Alcalà, 2009). We investigated the seasonal variability of this spatial gradient by computing the variation of monthly chlorophyll $a$ climatology moving from west to east along the basin (Fig. 3). In Fig. 3, each coloured line represents a climatological month and the chlorophyll $a$ value at a given longitude is obtained by averaging all the sea pixels from north to south, excluding those closer than $20 \mathrm{~km}$ from the coast to restrict the calculation to open ocean waters.

A decreasing trend of this surface chlorophyll $a$ mean concentration, moving from west to east, is observed in all the months of the year (Fig. 3). The curves highlight the occurrence of an enhanced seasonal cycle in the western Mediterranean with respect to the eastern Mediterranean, generally characterized by oligotrophic conditions in all the months of the year. Oligotrophic conditions dominate in the western Mediterranean Sea during summer, while during spring the occurrence of the blooms is marked by two distinct peaks at 4 and $9^{\circ} \mathrm{E}$ associated with the Gulf of Lion and the Ligurian Sea, respectively. The peak at $13^{\circ} \mathrm{E}$, instead, is the signature of the rich chlorophyll $a$ area of the North Adriatic Sea.

The observed west to east decreasing trend is consistent with a similar trend observed in the nutrient concentrations by Siokou-Frangou et al. (2010) and by Santinelli et al. (2012). These concentrations are generally very low, according with the general oligotrophy of the basin, and are mainly linked to the lack of phosphorous, which represents a limiting factor for a phytoplankton community's growth (Zohary and Robarts, 1998; Ribera D’Alcalà et al., 2003; Krom et al., 2004).

Figure 3 clearly reveals that April is the month in which the maximum excursion of chlorophyll $a$ across the basin occurs, while August shows a minimum of the longitudinal gradient. In these 2 months we observed the two extremes of the annual chlorophyll $a$ variability in all the Mediterranean subbasin, expect for the Adriatic Sea. Therefore, in the next subsessions we focus on these contrasting months for analysing the variation of the spatial distribution of micro-, nano-, and pico-phytoplankton in the Mediterranean Sea resulting from the application of the BR model. However, the maps of entire climatological time series can be found in the Supplement.

\subsection{Micro-phytoplankton}

The seasonal spring to summer excursion of microphytoplankton, in the first optical depth, is shown in Fig. 4. In August, excluding the coastal areas, the micro-phytoplankton is uniformly distributed over the entire Mediterranean and its contribution to the total chlorophyll $a$ is low, with val- 


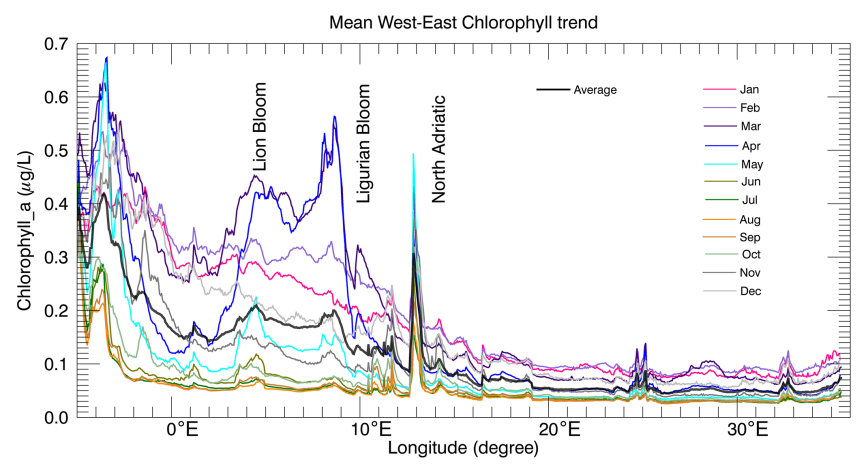

Figure 3. West to east climatological monthly mean chlorophyll $a$ concentration $\left(\mu \mathrm{g} \mathrm{L}^{-1}\right)$ over the basin for the time series 1998 2010. The coloured lines are built up averaging all pixels from north to south for each longitude degree of the basin, moving from west to east. The high chlorophyll $a$ values of the Gulf of Lion, Ligurian Sea and North Adriatic Sea are highlighted in the figure (see also the map of the Mediterranean Sea in Fig. 1).

ues of about $12 \%$ in the Ionian-Levantine Basin, $13 \%$ in the western basin, and relative peaks of $15-25 \%$ in the Alborán Sea. These low values are associated with low chlorophyll $a$ concentrations. Indeed, in summertime, the water becomes warmer and the stratification of the column is more marked, thereby producing a resistant thermocline that limits the transfer of nutrients to surface and consequently determines a reduced photosynthetic activity (Siokou-Frangou et al., 2010). This pattern persists also in June and July (see additional material). In August, high values of microphytoplankton contribution are observed in some coastal regions characterized by a high nutrient supply due to upwelling or river runoff: the Alborán Sea, the North Adriatic Sea, the Gulf of Lion and the Gulf of Gabes with values ranging between 35 and $75 \%$. In the Alborán Sea, the higher micro-phytoplankton contribution is highlighted by water upwelled along the Spanish coast and entrained in the west Alborán Gyre (Sarhan et al., 2000).

In April, instead, the fraction of micro-phytoplankton significantly grows in the Northwestern Mediterranean Sea reaching values from 30 to $57 \%$. This area, included by D'Ortenzio and Ribera d'Alcalà (2009) in the bloom cluster, is characterized by a local dynamic in which cold winter winds can induce deep mixing extending down to several hundred and up to $1000 \mathrm{~m}$, a value that is large when compared to the seasonal winter overturn. This deep overturning process also brings up an additional supply of nutrients complementary to that furnished by seasonal convection, thus modulating the spring bloom. The bloom observed in April (Fig. 4) is the result of winter upwelled nutrients and phytoplankton trapped in the euphotic zone by the spring restratification process and by the increased insolation. After this high productivity period, the micro-phytoplankton con-

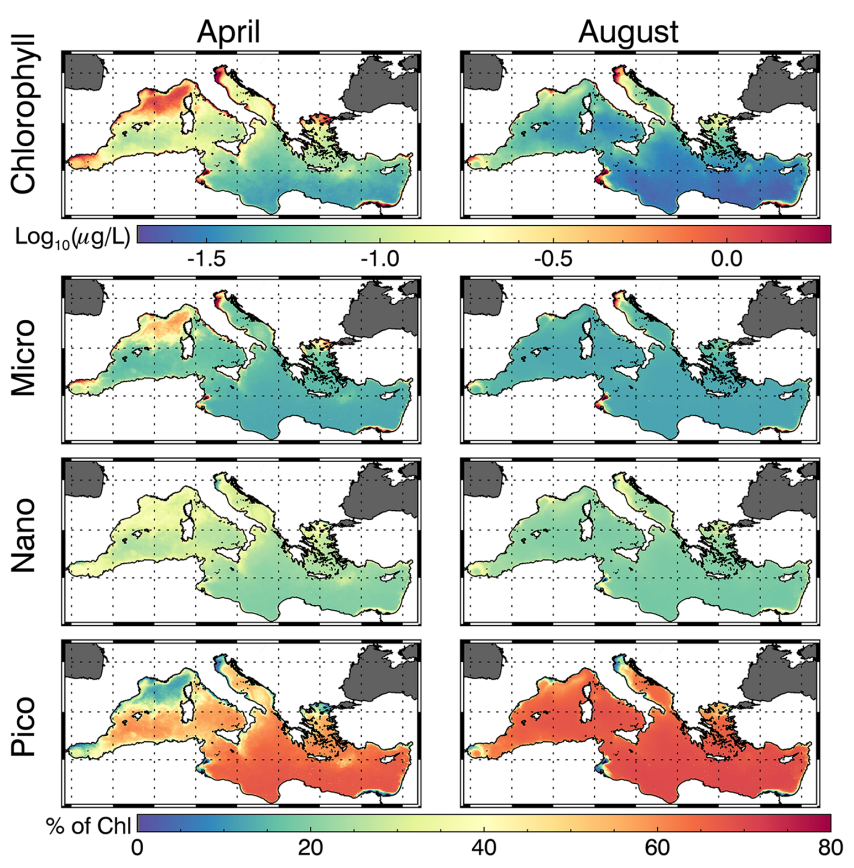

Figure 4. Seasonal spring to summer excursion of TChl $a$ and PSCs in the Mediterranean Sea. On the left panels, the April climatology (1998-2010) maps of TChl $a\left(\mu \mathrm{g} \mathrm{L}^{-1}\right)$ and PSCs $(\%)$. On the right panels, the August climatology (1998-2010) maps of TChl $a$ $\left(\mu \mathrm{g} \mathrm{L}^{-1}\right)$ and PSCs $(\%)$.

tribution to the TChl $a$ decreases in the whole basin, reaching its minimum in August-September.

In April, high micro-phytoplankton values are still present in the same coastal areas where micro-phytoplankton predominates in August, with the addition of the north Aegean Sea where the signature of the Black Sea outflow is now evident in the chlorophyll map (Fig. 4). Differently from August, the Spanish coastal water reaches also the eastern Alborán Gyre, resulting in a widespread region characterized by the micro-phytoplankton component.

In the Ionian-Levantine Basin, the contribution of the micro-phytoplankton remains low with values about of $12-$ $13 \%$ and with higher values ranging from 15 to $21 \%$ in the western side of the Ionian Sea and in the area west of Rhodes Island where the presence of the Rhodes Gyre facilitates the uplift of nutrients from the deeper layer.

Yet, in the western basin, an increase of the microphytoplankton fraction occurs during the entire autumn/winter seasons (not shown) due to water column becoming mixed after the breakdown of the thermocline (Bosc et al., 2004). Unlike the spring bloom, the values of chlorophyll $a$ are now lower, in agreement with previous observations (Siokou-Frangou et al., 2010). This phenomenon leads to a minor percentage of micro-phytoplankton close to $20 \%$ of the TChl $a$, with some peaks in the Algerian Current that flows along the southern boundary of the western Mediterranean $(25-40 \%)$. The eastern basin still shows low frac- 
tions of the micro-phytoplankton component during the autumn/winter months (see November-February maps in the Supplement).

\subsection{Nano-phytoplankton}

The amplitude of the seasonal cycle of the nanophytoplankton component is less pronounced than the microphytoplankton (Fig. 4). In summer, the contribution of the nano-phytoplankton to the total chlorophyll $a$ is between 18 and $24 \%$. In coastal areas, such as the North Adriatic Sea, its contribution to total chlorophyll $a$ reaches $25-38 \%$, with a decrease for pixels closer to the coast where microphytoplankton still dominates (Fig. 5a).

In April, the contribution of the nano-phytoplankton remains between 20 and $25 \%$ in most of the Ionian-Levantine Basin, with the exception of the Rhodes Gyre, where it reaches values of about $29 \%$ and the western Ionian Sea, where values of up to $30-36 \%$ are observed approaching the coasts of Italy (Fig. 4). In the western Mediterranean Sea, the values of nano-phytoplankton contribution to total chlorophyll $a$ vary from 25 to $38 \%$ (Fig. 4). Yet, in the North Adriatic Sea, the nano-phytoplankton fraction, in April, is always between 20 and $36 \%$ but with a more evident decrease, with respect to August, for those pixels that are closer to the coast, where the micro-phytoplankton remains predominant (Fig. 5b). The variability of the nano-phytoplankton component in the remaining months of the year (autumn/winter) is not so high and still shows higher values in the western basin (28-30\%) than in the eastern basin (20-25\%), reaching peak values of $38 \%$ in gyres of the Alborán Sea and along the Algerian Current.

In these months, as in the spring, the division, in terms of oligotrophy, of the eastern basin with respect to the western basin is more evident; otherwise, the months from July to September reveal, in the open ocean, an invariable pattern of the nano-phytoplankton component.

\subsection{Pico-phytoplankton}

Due to the high surface/volume ratio, pico-phytoplankton seems to be more suitable to nutrient-poor environments often characterized by high salinity, such as those that occur in the Levantine Basin (Le Quéré et al., 2005). As suggested by Uitz et al. (2012), its capacity to survive in this type of environments justifies its great abundance in the eastern basin, thus becoming the principal producer in ultra-oligotrophic waters.

Indeed, Fig. 4 shows that in August the picophytoplankton contributes to $60-70 \%$ of the TChl $a$ in the offshore waters while lower values are observed in coastal waters: about 15-30\% in the western Alborán Gyre, $11-24 \%$ in the North Adriatic Sea and 12-34\% in the Gulf of Lion. In April, in the Ionian-Levantine Basin, the pico-phytoplankton fractions values remain high but lower
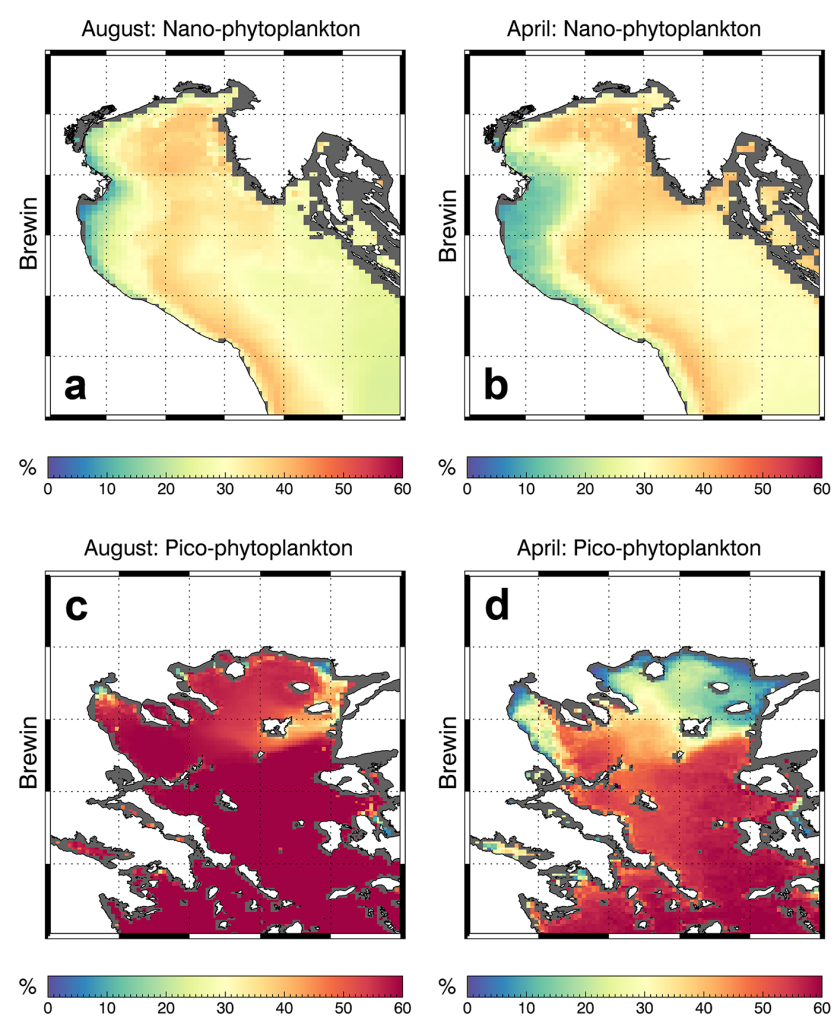

Figure 5. Seasonal spring to summer excursion of nano- and pico-phytoplankton fractions (\%) of TChl $a$ in two sectors. Nanophytoplankton percentages in the North Adriatic Sea for August (a) and April (b) climatology (1998-2010). Pico-phytoplankton percentages in the Aegean Sea for August (c) and April (d) climatology (1998-2010).

than those observed in August (64-65\%), while in the Northwestern Mediterranean Sea a large area of low picophytoplankton TChl $a$ concentration occurs with values ranging between 13 and $24 \%$. Similarly, low values are observed in coastal regions, e.g. in the north Aegean Sea, where the outflow of the Black Sea influences the distribution of the pico-phytoplankton class, with values ranging from 40 to $45 \%$ in August (see also Fig. 5c). In April, the outflow of the Black Sea waters is marked by a minimum, which ranges between 13 and $20 \%$ and which now affects all the northern part of the Aegean Sea (Fig. 5d).

The analysis of the January to April maps (Supplement) shows that pico-phytoplankton component reveals a contrasting variability moving from west to east, with high percentages in the latter and lower in the former. With the arrival of the summer season, the pico-phytoplankton seems to cover homogenously all of the basin with values of $70 \%$ and minima in correspondence with coastal areas. Later, the picophytoplankton decreases in the most dynamic areas, such as along the Tunisian coast, in conjunction a micro- and nanophytoplankton fraction increase (see e.g. December maps in the Supplement). This is caused by the intrusion of new nu- 

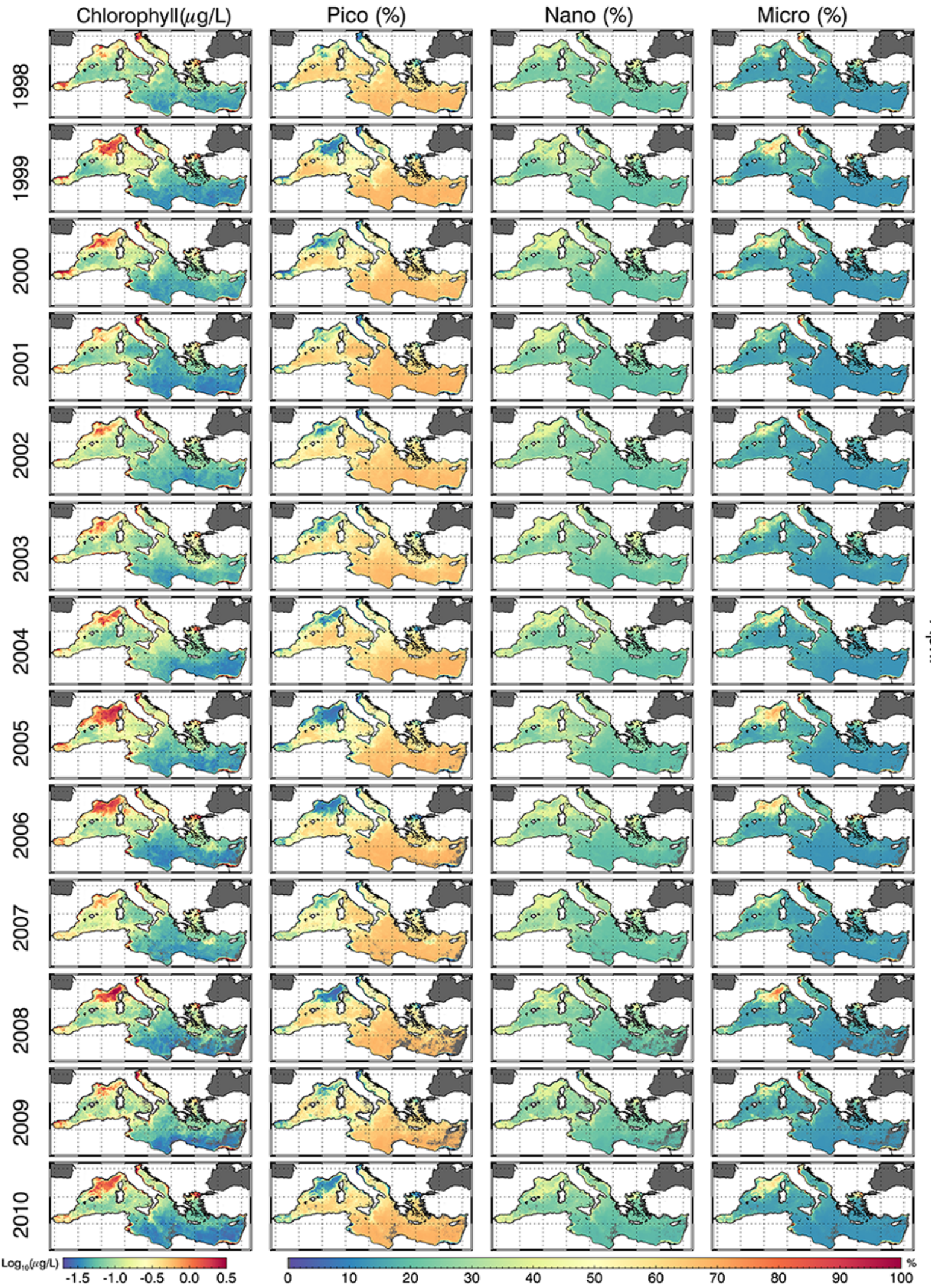

Figure 6. Monthly maps of inter-annual variability (1998-2010) of TChl $a$ and PSCs over the entire basin for April. The first panel refers to TChl $a\left(\mu \mathrm{g} \mathrm{L}^{-1}\right)$, the second to the pico-phytoplankton fraction on TChl $a(\%)$, the third and the fourth, respectively, refer to the nano- and micro-phytoplankton fractions (\%). 

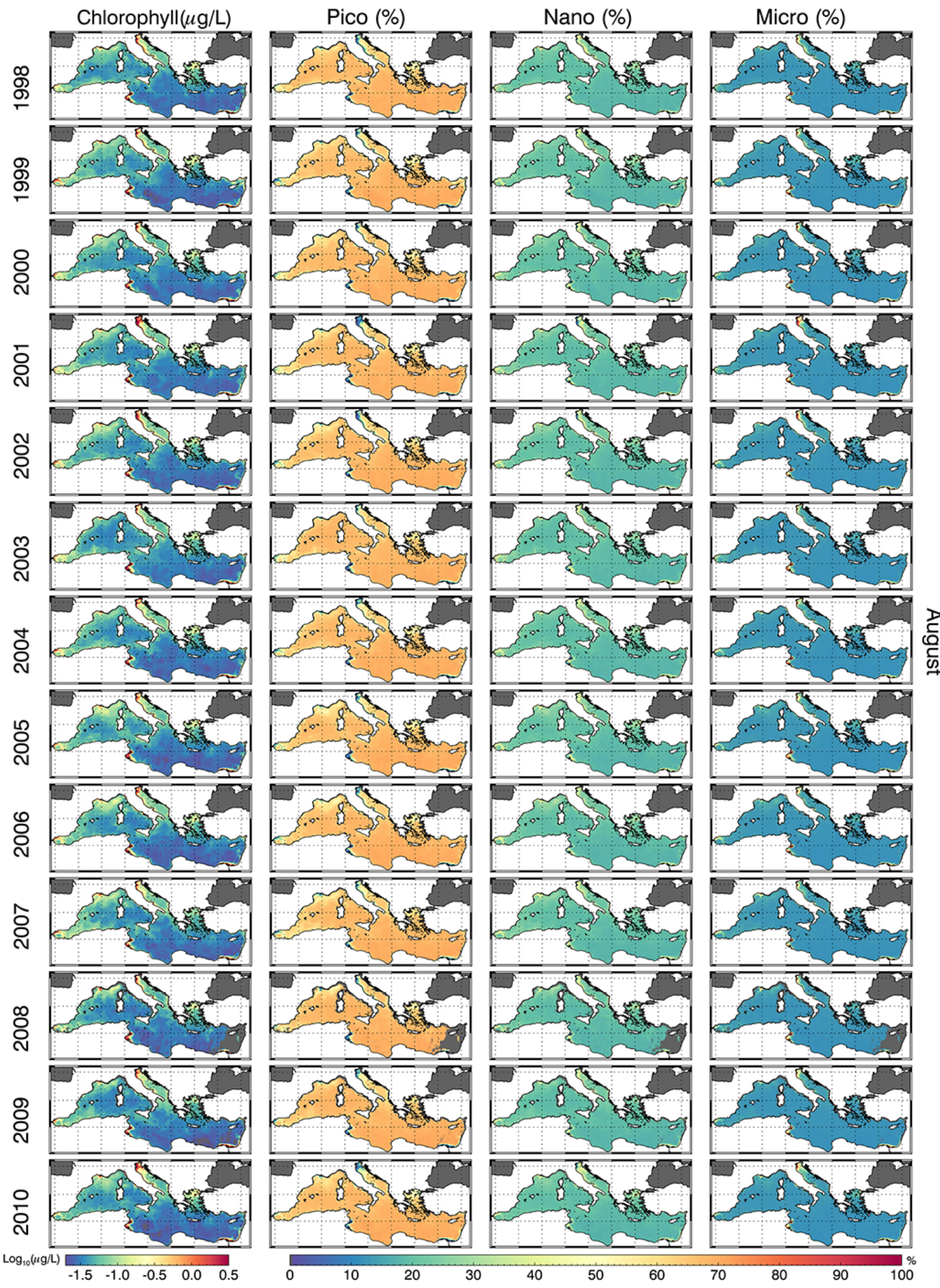

Figure 7. Monthly maps of inter-annual variability (1998-2010) of TChl $a$ and PSCs over the entire basin for August. The first panel refers to TChl $a\left(\mu \mathrm{g} \mathrm{L}^{-1}\right)$, the second to the pico-phytoplankton fraction on TChl $a(\%)$, the third and the fourth, respectively, refer to the nanoand micro-phytoplankton fractions (\%). 
trients from the deeper layer, due to the break of the thermocline.

\section{Inter-annual variability of chlorophyll $a$ and PSCs in the Mediterranean Basin}

The inter-annual variability of the surface chlorophyll $a$ and PSC distribution in the Mediterranean Sea is shown in Figs. 6 and 7 for the two opposite months of April and August, respectively. In addition, the chlorophyll $a$, micro, nano- and pico-phytoplankton fraction anomalies (respect to SeaWiFS climatology) have been computed and then averaged at basin scale in order to identify potential interannual signals and changes that occurred during the SeaWiFS era. Figure 8 shows that, at basin scale, the inter-annual signal is very small (the anomalies ranged from -0.04 to $0.06 \mu \mathrm{g} \mathrm{L}{ }^{-1}$ ) with positive anomaly peaks observed in winter 1999 and spring 2005 and 2006 as well as in March 2009, indicating that the inter-annual signal is essentially driven by the intensity of the spring bloom. From the analysis of the anomalies it emerges also that pico-phytoplankton oscillates between reduced ranges of positive (maximum nearly to $0.02 \mu \mathrm{g} \mathrm{L}^{-1}$ ) and negative anomalies $(-0.01 \mu \mathrm{g} \mathrm{L}-1)$, followed by the nano-phytoplankton component (maximum nearly to $0.03 \mu \mathrm{g} \mathrm{L}^{-1}-$ minimum $-0.02 \mu \mathrm{g} \mathrm{L}{ }^{-1}$ ), while the micro-phytoplankton falls in higher anomaly ranges (maximum $0.04 \mu \mathrm{g} \mathrm{L}^{-1}-$ minimum $-0.03 \mu \mathrm{g} \mathrm{L}^{-1}$ ).

The analysis of the April and August maps reveals that year-to-year variations are very small in August. In April, significant variations are observed: the pico-phytoplankton component dominates the TChl $a$ concentration with percentages of about 60-70\% over the entire basin, except areas of the western basin characterized by high and complex dynamics of the water masses. In these regions an enhanced inter-annual signal is observed. In the eastern basin these high values of pico-phytoplankton remain constant in all years, while in the western basin the areas most affected by a strong decrease of the pico-phytoplankton TChl $a$ contribution are located in correspondence to the Gulf of Lion and in the Alborán Sea. The April time series maps (Fig. 6) reveal that 1999, 2005 and 2006 are the years of highest chlorophyll $a$ concentrations in the Gulf of Lion and in the coastal zones of the basin. Here the contribution to TChl $a$ of picophytoplankton clearly decreases reaching values smaller than $10 \%$, while, at the same time, the micro-phytoplankton component increases up to $60-70 \%$, thus becoming predominant with respect to the pico- and the nano-phytoplankton fractions, the latter of which remains around $30-38 \%$. This behaviour results in a positive peak of micro-phytoplankton in the 2005 and 2006 anomalies time series (Fig. 8). The April maps reveal that the nano-phytoplankton component is not subjected to a significant year-to-year variation; however, a west to east gradient is visible in all years with maximum values located offshore the Gulf of Lion, where the inter-annual variability is more evident. The west to east
Mediterranean oligotrophic gradient is reflected in the April micro-phytoplankton maps (Fig. 6), where the contribution to TChl $a$ of the largest cells is very low, $15-19 \%$ along the entire time series, highlighting the influence that nutrientpoor environments, as those in the eastern basin, have on the micro-phytoplankton.

In August, the scenario is clearly different (Fig. 7). The chlorophyll $a$ concentration is very low in most of the offshore areas, although a slight increase of TChl $a$ can be observed from 2005 to 2007 in the western basin. The most evident signal of inter-annual variation is visible along the coastal zones of North Adriatic Sea. The low inter-annual variability observed in August affects also the pico- and nano-phytoplankton components but, differently from microphytoplankton, their contribution to TChl $a$ is higher, 65$70 \%$ for pico- and $19-20 \%$ for nano-phytoplankton. The analysis suggests that the seasonal and inter-annual signal observed in the TChl $a$ and pico-, nano-, and microphytoplankton time series is driven by local processes occurring in the Mediterranean Sea, only partially revealed by the present basin-scale analysis.

\section{Seasonal and year-to-year variability of chlorophyll $a$ and PSCs at local scale}

Local processes play an important role in the ecosystem of the Mediterranean Sea by interacting with the physical system that contributes to drive its evolution but that, in turn, is affected by it (biofeedbacks). To investigate the year-toyear variability of processes that occur at local scale in the Mediterranean Sea, we selected four key sub-regions: the Northwestern Mediterranean Sea (NWMed), the Levantine Basin (LEV), the Alborán Sea (ALB) and the North Adriatic Sea (NADR) (see coloured boxes in Fig. 1). In these regions relevant processes such as surface currents' advection, upwelling, water stratification or nutrients and river inputs occur, modulating local ecosystem variability. Results of this analysis were synthesized in Fig. 9.

In NWMed Sea (Fig. 9a) the seasonal cycle of chlorophyll $a$ concentration shows an increase of TChl $a$ values from the initial part of the year, January-February, with maximum values in April and in March ranging from 0.4 to $1.2 \mu \mathrm{g} \mathrm{L}^{-1}$. In summer, the chlorophyll $a$ decreases up to $0.06 \mu \mathrm{g} \mathrm{L}^{-1}$, and then, in autumn, it rises again. The analysis of the year-to-year variability reveals an absolute spring maximum in April 2005 (Fig. 9a), with a concentration of about $1.2 \mu \mathrm{g} \mathrm{L}^{-1}$, followed by a decreasing trend from 2006 to 2007 and a new rising in $2008\left(0.9 \mu \mathrm{g} \mathrm{L}^{-1}\right)$. From this year onwards, the lack of some months is due to the fewer number of observations recorded by SeaWiFS from 2007 to 2010. The accuracy of the TChl $a$ variability in the NWMed sector is taken into account computing and evaluating the anomalies over the time series from 1998 to 2010 (Fig. 10a). From Fig. 10a, we see that negative anomalies are more frequent 

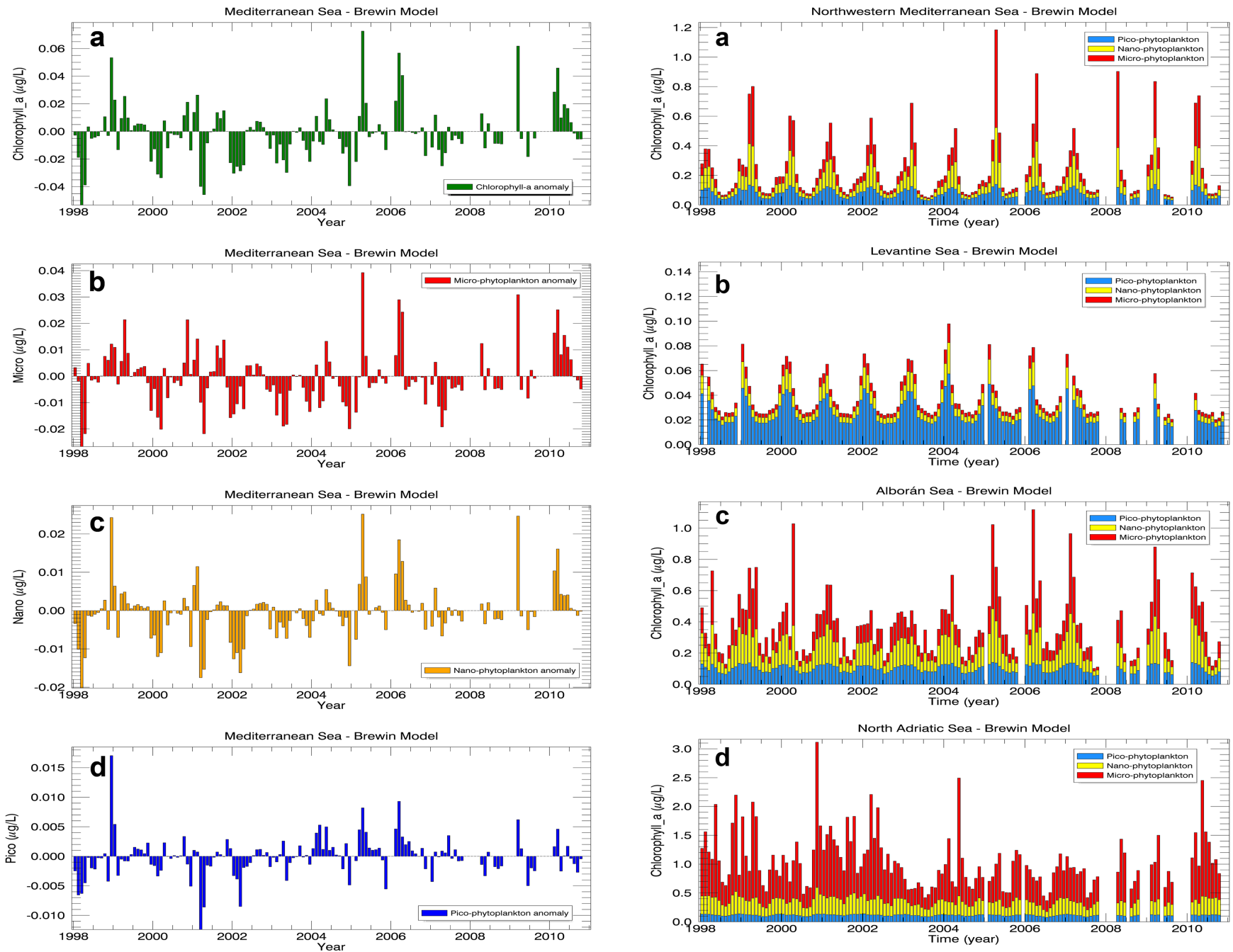

Figure 8. Monthly anomalies computed for the entire time series (1998-2010) over the Mediterranean Basin. Gaps in the time series correspond to months where less than $90 \%$ of the observations were recorded in the basin. From top to bottom, there are the anomalies of TChl $a$, micro-phytoplankton contribution to TChl $a$, nanophytoplankton contribution to TChl $a$, and pico-phytoplankton contribution to TChl $a$.

and stronger than the positive ones, especially in the first part of the time series. These types of oscillations still persist up to 2005 , when the highest positive spring anomaly occurs $\left(0.6 \mu \mathrm{g} \mathrm{L}^{-1}\right)$, followed by the April 2006 and 2008 positive anomalies.

The mean annual values of chlorophyll $a$ concentration for NWMed and ALB (Fig. 9a, c) are quite similar; however, in the latter (Fig. 9c) the seasonal cycle is less "clean" and the year-to-year variability is marked by minimal values of the spring maxima from 2001 to 2004 ranging from 0.5 to $0.7 \mu \mathrm{g} \mathrm{L}^{-1}$ and relative maxima in 2000, 2005, 2006 and 2007 ranging from 1.0 to $1.1 \mu \mathrm{g} \mathrm{L}-1$. Intermediate values of the spring maximum are observed in the remaining years of

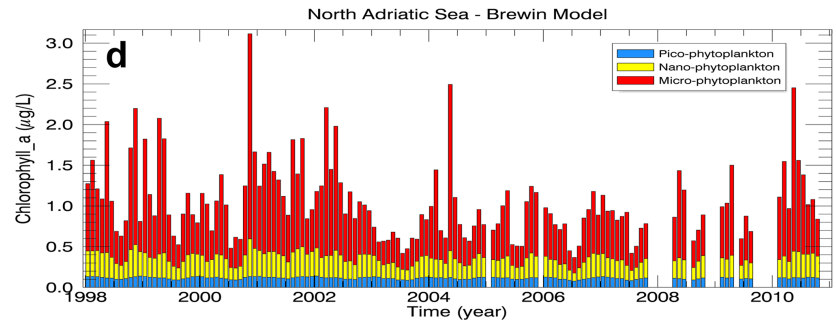

Figure 9. Inter-annual variability of the contribution of micro-, nano- and pico-phytoplankton to the TChl $a\left(\mu \mathrm{g} \mathrm{L}^{-1}\right)$ from 1998 to 2010 in the four sectors: Northwestern Mediterranean Sea (a), Levantine Sea (b), Alborán Sea (c), and North Adriatic Sea (d). Gaps in the time series correspond to months where less than $90 \%$ of observations were recorded in the region.

the series. The "chaotic" pattern of the TChl $a$ in the Alborán Sea is also reflected in the corresponding anomaly (Fig. 10c). In this case, the positive and negative anomalies vary between -0.4 and $+0.5 \mu \mathrm{gL}^{-1}$. The time series anomaly reveals that the main positive peaks occur in April 2000, March 2006 and February 2007; the same peaks highlighted in the inter-annual analysis (Fig. 9c). Negative anomalies prevail in 2002 and 2003.

Differently from the ALB Sea, in the LEV basin (Fig. 9b) the seasonal cycle of the chlorophyll $a$ concentration is more regular. It rapidly increases from early winter months, reaching local maxima values in January-February. In summer, the chlorophyll $a$ reaches minimum values and then it increases again in autumn. In Fig. 9b peak values appear in 

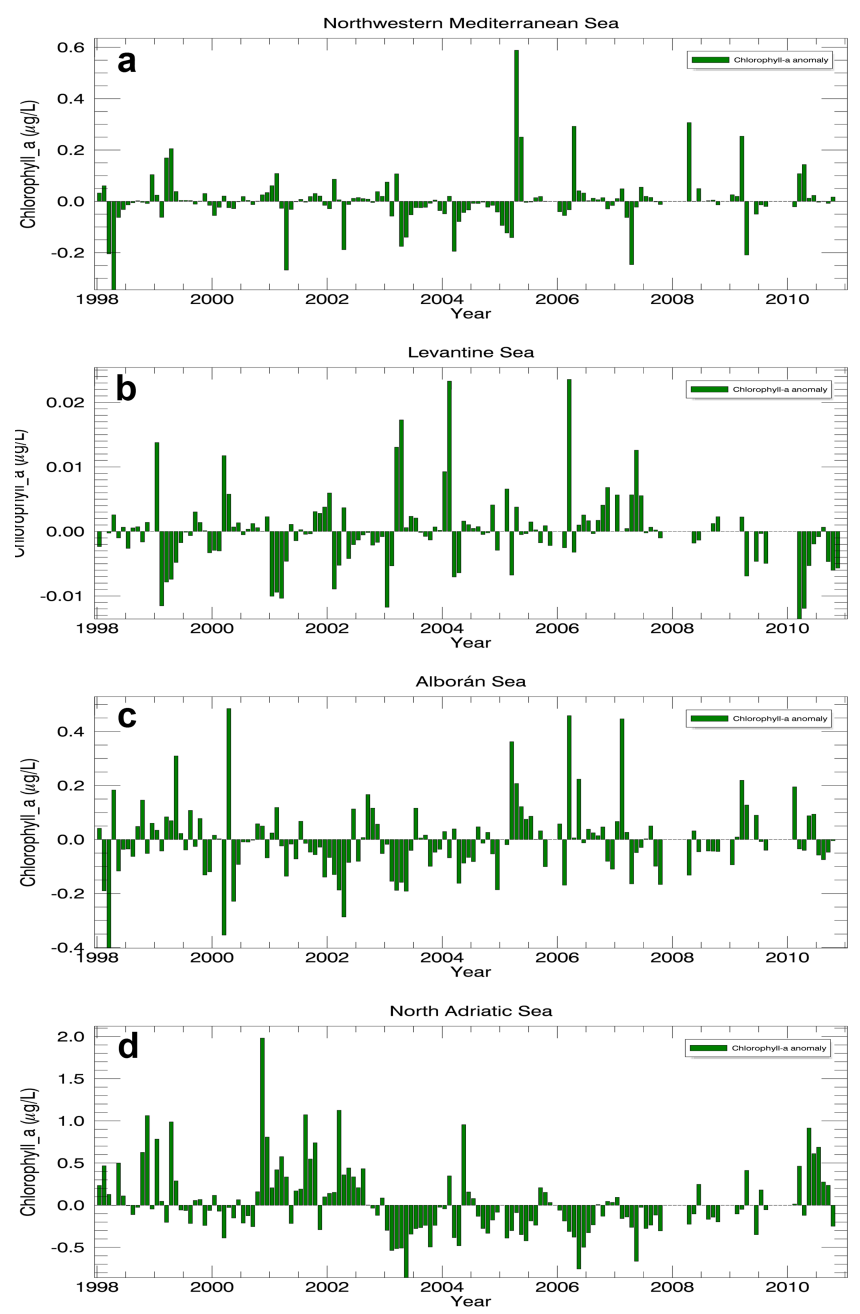

Figure 10. Monthly anomalies of TChl $a$ computed for the entire time series (1998-2010) over each of the four sectors. Gaps in the time series correspond to months where less than $90 \%$ of the observations were recorded in the region. From top to bottom there are the anomalies of TChl $a$ in the Northwestern Mediterranean Sea (NWMed), Levantine Sea (LEV), Alborán Sea (ALB) and North Adriatic Sea (NADR).

January 1999 and February 2004, reaching chlorophyll $a$ concentrations of about $0.08-0.10 \mu \mathrm{g} \mathrm{L}^{-1}$. Among all basins, the anomaly time series of the Levantine Basin (Fig. 10b) is characterized by the smallest oscillations, ranging from -0.01 to slightly more than $0.02 \mu \mathrm{g} \mathrm{L}^{-1}$. Despite these low values, positive peaks occur in 2004 and 2006, while from 1998 to 2003 the times series is dominated by negative values.

Differently form the LEV, where chlorophyll $a$ concentrations are almost 1 order of magnitude lower than in the other sub-basins, the NADR (Fig. 9d) exhibits the highest values of chlorophyll $a$ concentration. In NADR, summer minima never reach values as low as those observed in the other three sub-regions contributing to mask the seasonal signal. The NADR inter-annual variability of the chlorophyll $a$ concen- tration is expressed by an irregular trend from 1998 to 2002, a local minimum during 2003 and then a more weakened variability from the end of 2005 to 2009 . In this case, the main peaks occur in 2000, 2004 and 2010, while 2003 represents the year of the lowest oscillation. North Adriatic Sea anomalies (Fig. 10d) are the most intense among the four sectors, reaching positive values as high as $2.0 \mu \mathrm{g} \mathrm{L}^{-1}$ in 2000 and negative values as low as $-0.85 \mu \mathrm{g} \mathrm{L}^{-1}$ in 2003 .

In the NWMed basin (Fig. 9a), the contribution of picophytoplankton to the seasonal cycle seems to be constant from year to year, with values not higher than $0.14 \mu \mathrm{g} \mathrm{L}^{-1}$ and a mean concentration of $0.08 \mu \mathrm{g} \mathrm{L}^{-1}$. Although the differences between minima and maxima of pico-phytoplankton in each year are low, it, however, follows a seasonal variability, with higher values in late winter-early spring and lower values in summer.

Nano-phytoplankton shows the same seasonal cycle of pico-phytoplankton (Fig. 9a). Both maxima and minima occur in the same months of the smallest cells but, in this case, the excursion among them is higher with respect to those of pico-phytoplankton. The peaks occur during the early spring season, reaching an absolute maximum of $0.38 \mu \mathrm{g} \mathrm{L}^{-1}$ in April 2005 with an annual mean of $0.08 \mu \mathrm{g} \mathrm{L}^{-1}$. In the NWMed, the largest seasonal variability is due to microphytoplankton. Maximum values occur during the spring blooms season, with the highest peak of about $0.7 \mu \mathrm{g} \mathrm{L}^{-1}$ in April 2005. During summer, micro-phytoplankton reaches very low concentrations, below $0.02 \mu \mathrm{g} \mathrm{L}^{-1}$.

In contrast with the NWMed sector, pico-phytoplankton predominates in the LEV (Fig. 9b) all year-round with a mean concentration of $0.03 \mu \mathrm{g} \mathrm{L}^{-1}$ (Fig. 9b) and a seasonal cycle nearly constant from year to year.

The nano-phytoplankton component shows a higher variability and large seasonal differences between minima and maxima. The peak values usually occur in January-February while low concentrations are reached in summer with a mean year concentration slightly higher than $0.01 \mu \mathrm{g} \mathrm{L}^{-1}$.

Furthermore, the strong and well-known oligotrophy of this basin is reflected in the fraction of micro-phytoplankton, the lowest among the three PSCs, with a mean that is very close zero.

Among all the four sectors, the ALB (Fig. 9c) and NADR (Fig. 9d) basins show an irregular inter-annual variability with a nearly absent seasonal cycle in the NADR.

In the ALB basin (Fig. 9c) the pico-phytoplankton concentration are relatively low and nearly constant along the entire period (mean value of $0.1 \mu \mathrm{g} \mathrm{L}^{-1}$ ), with small peaks occurring during spring months.

Nano-phytoplankton follows the same pattern of picophytoplankton, but with a higher excursion between minima and maxima. The absolute peak for nano-phytoplankton component is in March 2005, with a concentration of 0.30 to $1.00 \mu \mathrm{g} \mathrm{L}^{-1}$ of TChl $a$.

For the ALB, we observe a less clean seasonal cycle and a reduced year-to-year variability, specially for the 
micro-phytoplankton fraction. Micro-phytoplankton shows a seasonal oscillation with the usual increase during spring blooms and a decrease in summer, as a result of a stratification of the water column. The mean contribution of microphytoplankton to the TChl $a$ is about of $0.15 \mu \mathrm{g} \mathrm{L}{ }^{-1}$, while the maximum is $0.7 \mu \mathrm{g} \mathrm{L}^{-1}$ in March 2006.

In the NADR basin (Fig. 9d) the seasonal signal is absent or, at least, not immediately visible. In contrast with the other basins, the chlorophyll $a$ content is very high and the PSC ratios show a different behaviour with respect to the other sectors. The pico-phytoplankton fraction is nearly constant along the entire time series with low or absent seasonal variations. The pico-phytoplankton mean fraction of the value of TChl $a$ is $0.11 \mu \mathrm{g} \mathrm{L}^{-1}$, which is still higher than the mean value $\left(0.03 \mu \mathrm{g} \mathrm{L}^{-1}\right)$ of the LEV (Fig. 9b).

In NADR, the highest contribution to the TChl $a$ is provided by the micro-phytoplankton (mean value $0.7 \mu \mathrm{g} \mathrm{L}^{-1}$ ). It also shows inter-annual variations but with peaks that occur in different years with respect to the other three sectors. Figure $9 \mathrm{~d}$ reveals constant high values of micro-phytoplankton in 2001 and 2002, two peaks in November $2000\left(3.1 \mu \mathrm{g} \mathrm{L}{ }^{-1}\right)$ and in May $2004\left(2.5 \mu \mathrm{g} \mathrm{L}^{-1}\right)$ and the lowest values in 2003.

\section{Discussion and conclusions}

In this work, for the first time, we estimate the contribution of micro-, nano- and pico-phytoplankton to the total chlorophyll $a$ over the Mediterranean Sea by applying an abundance-based model (Brewin et al., 2011b, referred to as BR) to the entire time series of the SeaWiFS mission. Since the selected model was developed by using data sets from many different regions of the ocean, we started by verifying its accuracy for the Mediterranean case.

This validation showed that the model constantly underestimates nano-phytoplankton fractions over the entire range of observed TChl $a$ concentrations, while it overestimates pico-phytoplankton concentrations for low TChl $a$ concentrations. These results lead us to think that the specific optical properties of this basin can be influenced by the phytoplankton community assemblage as suggested by Volpe et al. (2007). In fact, considering that each region can be characterized by a specific pigment content, we hypothesized that the different pigment ratios can represent one of the possible reasons that can justify the observed deviation of the model from the in situ PSC classification. Therefore, we first investigated whether the global relation between DP and chlorophyll $a$, used by the BR model, is still valid for the Mediterranean Sea and whether the use of a regionally tuned relation can contribute to reduce the observed bias between modelled and measured PSCs. Our results demonstrate that the use of a regional Mediterranean DP function (Di Cicco, 2014) reduces the bias to values comparable with those obtained by BR at global scale and suggest that a retuning of the empirical BR model coefficients is not a priority, with respect to the main goal of this work. We concluded that the BR model, even if developed for the global ocean, can still be used in the Mediterranean Sea considering that, when applied to satellite data, the major source of uncertainty is the chlorophyll $a$ determination. However, the use of daily chlorophyll $a$ data, reprocessed with a regional Mediterranean algorithm for Case 1 and Case 2 waters, allows us to account for the unique optical properties of the Mediterranean Sea, thus reducing the bias between in situ measured and satellite chlorophyll $a$ estimate to nearly zero $\left(-0.02 \mathrm{mg} \mathrm{m}^{-3}\right)$ with a relative small RMS $\left(0.25 \mathrm{mg} \mathrm{m}^{-3}\right.$ ) (see Table 4 in Volpe et al., 2012a).

The analysis of micro-, nano- and pico-phytoplankton satellite time series (1998-2010) allowed, for the first time, for a quantitative description of the seasonal and inter-annual variability of the spatial distribution of the algal assemblage structure. The results indicate that pico-phytoplankton dominates year-round in most of the Mediterranean Basin, particularly in ultra-oligotrophic waters. Nevertheless, exceptions are the Northwestern Mediterranean Sea (during the spring bloom), the Alborán Sea, and several coastal areas such as the North Adriatic Sea. In the coastal areas, the contribution of micro-phytoplankton to TChl $a$ is always more evident and can be explained by the high typical nutrient conditions of these regions, which favour the predominance of microphytoplankton with respect to the other two size classes (e.g. Siokou-Frangou et al., 2010). On the contrary, in the offshore waters the contribution of nano-phytoplankton to TChl $a$ is of the order of 20-40\%, remaining mostly constant throughout the year (Fig. 4). This is consistent with the nanophytoplankton's constant contribution to the Mediterranean primary production observed by previous authors (Uitz et al., 2010, 2012).

In ultra-oligotrophic waters, such as those of the Levantine Basin, pico-phytoplankton prevails in the PSC climatology (Sect. 4). This is justified by the ability of the smallest cells to exploit better the nutrient-poor environments, according to their high surface-to-volume ratio (Le Quéré et al., 2005; Timmermans et al., 2005). Indeed, the summer stratification of the water column causes a strong decrease in micro-phytoplankton chlorophyll $a$ contribution, whereas nano-phytoplankton and pico-phytoplankton survive adapting to the warmer water state (Fig. 4) (Marty and Chiaverini, 2002).

The typical chlorophyll $a$ seasonal cycle of the temperate regions occurs in the Mediterranean Sea, with maxima in spring and minima in summer. It results in a seasonal signal of the PSC distribution, characterized by an increase in the micro-phytoplankton fraction in spring and the picophytoplankton fraction in summer (Fig. 4). This mean seasonal cycle can be significantly distorted in coastal regions, such as the North Adriatic Sea (Fig. 4), where terrestrial inputs from rivers play an important role in modulating the nutrient supply in the upper layer of the water column. In this basin, the micro-phytoplankton class dominates year-round, in accordance with the knowledge resulting from in situ mea- 
surements of the LTER (Italian Long-Term Ecological Research Network) North Adriatic station (Fonda Umani et al., 2005; Cataletto et al., 2012). In addition, in the Alborán Sea, in which the Atlantic inflow modulates the nutrient availability, an intermediate temperate and sub-tropical seasonal cycle is observed, with a chlorophyll $a$ maximum in late winterearly spring (Siokou-Frangou et al., 2010). In this region, our analysis reveals that, in general, there is not an evident predominance of one class over the others all along the year (Fig. 9c). Micro-, nano- and pico-phytoplankton contributions to TChl $a$ are modulated by intermitted processes, such us the variation of the Atlantic flow and upwelling events occurring along the Spanish coast, which can cause a vertical uplift of nutrients, especially nitrates, to the surface water layer (Mercado et al., 2005).

Inter-annual variability is observed in the entire basin, but the largest inter-annual signal occurs in the Northwestern Mediterranean Sea, driven by the year-to-year variation of the intensity and extension of the spring bloom (Fig. 6). During spring, relatively high values of chlorophyll $a$ are observed in the whole basin (Fig. 6) but above all in the western basin and particularly in 1999, as reported in Volpe et al. (2012b). A general decrease of spring chlorophyll $a$ concentrations occurs in 2001, affecting mostly the eastern basin, confirming the Bosc et al. (2004) results. This decrease is reflected in a lower contribution of the microphytoplankton fraction on the TChl $a$ (Fig. 6). A peak of chlorophyll $a$ signal occurs in April 2005, accompanied by an increase of micro-phytoplankton with respect to previous years (Figs. 6, 8b). These anomalous high values of the averaged spring chlorophyll $a$ field are associated with an overall increase in the concentration of chlorophyll $a$, which occurs in the entire western Mediterranean Basin. They are also linked to an intensification of the spring bloom in the Gulf of Lion (see Fig. 6), where an unusual and strong winter convention occurred in the 2005 (Volpe et al., 2012b; Font et al., 2007; Smith et al., 2008). This phenomenon results in a local increase of the micro-phytoplankton fraction with respect to previous years even though the nano- and pico-phytoplankton contributions to total chlorophyll $a$ remain dominant at basin scale (Fig. 6). A second spring maximum is observed in 2008 in both chlorophyll $a$ and microphytoplankton (Fig. 6), related again to the enhancement of the spring bloom in the Gulf of Lion.

The analysis of the year-to-year variability in the PSCs of the NWMed (Fig. 9a) confirms the occurrence of an evident seasonal and inter-annual signal. The seasonal cycle of chlorophyll $a$ and thus PSCs is the one typical of temperate areas, with maxima in March and/or April (Fig. 9a). During these spring blooms, the micro-phytoplankton exceeds the other classes, in light of the great amount of nutrients available in the water column. Indeed, in this area, the winter deep and intermediated convection allows bringing up nutrients from the deeper layer (Lévy et al., 1998a, b). This process modulates the year-to-year variability of intensity and dura- tion of spring bloom (Santoleri et al., 2003), which results in a strong inter-annual signal of the micro-phytoplankton concentration, as revealed by our analysis (Fig. 9a).

The micro-phytoplankton dominates the inter-annual signal also in the NADR, while both nano- and picophytoplankton show slight variations (Fig. 9d). The large contribution of the biggest cells to the high values of TChl $a$ can be related to the presence of big rivers, such as the Po, Brenta, Livenza, Adige and Isonzo. Every year, their runoff causes the release of a large amount of organic particles and nutrients that support the micro-phytoplankton's cell size growth and development. Our analysis shows that the peaks of micro-phytoplankton biomass usually occur in May and November (Fig. 9d), when the river runoff increases due to the more intense rainfall and snowmelt (Struglia et al., 2004; Malej et al., 1995). Anomalous events are recorded in November 2000 and May 2004 (Fig. 9d). In the former, the prevalence of micro-phytoplankton on the TChl $a$ can be due to the particular meteorological conditions that occurred in that year. Intense precipitations occurred for November 2000 in the Po hydrographic basin (Stravisi, 2006; Russo et al., 2005), with the consequent intensification of the river outflow. This intensification increased nutrient concentrations in the North Adriatic Sea, contributing to the increase of the micro-phytoplankton fraction, as revealed by our analysis. This is also in agreement with in situ observations of the LTER station, located in the Gulf of Trieste, which shows biomass peaks of the micro-phytoplankton fraction in the same year (Cataletto et al., 2012).

A contrasting case is the Levantine Sea, where the ultraoligotrophic regime influences the distribution and, in particular, the contribution of the three PSCs to the TChl $a$. Figure $9 \mathrm{~b}$ shows that most of the TChl $a$ is due to the pico-phytoplankton class, which is predominant throughout the year. This can be related to the ability of the smallest cells to live and survive in extreme conditions, such as nutrient-poor environments and a well-stratified water column (Siokou-Frangou et al., 2010; Le Quéré et al., 2005). When the bloom occurs (February), in addition to the picophytoplankton class, the nano-phytoplankton fraction also increases its contribution to TChl $a$.

In summary, in absence of sufficient in situ data of community composition, our time series analysis demonstrates the potential use of ocean colour imagery for monitoring the phytoplankton assemblage in the Mediterranean Basin. The possibility of identifying all the components of the phytoplankton assemblage, in terms of dimensional size, allowed us to provide complementary information to the present knowledge of the Mediterranean phytoplankton composition, which was based, so far, only on the dominant phytoplankton types (Navarro et al., 2014). Our analysis demonstrated that the predominance of one group over the others strongly depends on the physical and biological processes occurring at the mesoscale, which directly influences the nutrient and light availability, i.e, the principal force for the algae growth. 
Our analysis demonstrated that, in the evaluation of the contribution of each size class to TChl $a$, the ratio of diagnostic pigments in relationship to chlorophyll $a$ content is a key factor. This ratio represents one of the elements that is mostly affected by the characteristics of pigment content of each specific region, which itself influences all the algorithm retrieval processes. Moreover, this phenomenon can induce an eventual bias due to the seasonal and inter-annual changes in the relationship between size fraction and TChl $a$, thus representing a limit for the approaches that are based on the direct fitting of the model with in situ global or regional pigment data sets.

Since our important work does not aim to provide a specific regional product for PSCs, we are aware that more efforts need to be done on this regard. As a future perspective, we would like to extend our analysis to other satellite sensors in order to enlarge the PSC time series, but we will also consider and test other models, based on different variables, with the aim to track, as much as possible, the phytoplankton community evolution from space. Moreover, one of our future projects will be to regionalize one of these approaches, as well as the BR model, in order to improve an instrument to retrieve information about the PSC variability specifically for the Mediterranean Sea.

\section{The Supplement related to this article is available online at doi:10.5194/os-11-759-2015-supplement.}

Acknowledgements. This work was financially supported by the EU project FP 7 PERSEUS (Policy-oriented marine Environmental Research in the Southern EUropean Seas) grant agreement no. 287600 and the Italian RITMARE Flagship Project. This work was also supported by MyOcean-2: Prototype Operational Continuity for GMES Ocean Monitoring and Forecasting Service (grant agreement no. 283367). We are deeply grateful to Federico Falcini for his critique and constructive suggestions and Simone Colella for his great technical support and his advice during the revision phase.

Edited by: E. J. M. Delhez

\section{References}

Aiken, J., Pradhan, Y., Barlow, R., Lavender, S., Poulton, A., Holligan, P., and Hardman-Mountford, N. J.: Phytoplankton pigments and functional types in the Atlantic Ocean: a decadal assessment, 1995-2005, Deep Sea Res. Pt. II, 56, 899-917, 2009.

Agawin, N. S. R., Duarte, C. M., and Agusti, S.: Nutrient and temperature control of the contribution of picoplankton to phytoplankton biomass and production, Limnol. Oceanogr., 45, 591600,2000 .
Alvain, S., Moulin, C., Dandonneau, Y., and Bréon, F. M.: Remote sensing of phytoplankton groups in case 1 waters from global SeaWiFS imagery, Deep-Sea Res. Pt. I, 52, 1989-2004, 2005.

Alvain, S., Moulin, C., Dandonneau, Y., and Loisel, H.: Seasonal distribution and succession of dominant phytoplankton groups in the global ocean: a satellite view, Global Biogeochem. Cy., 22, GB3001, doi:10.1029/2007GB003154, 2008.

Antoine, D. and Morel, A.: Oceanic primary production: I. Adaptation of a spectral light-photosynthesis model in view of application to satellite chlorophyll observations, Global Biogeochem. Cy., 10, 43-55, 1996.

Antoine, D., André, J. M., and Morel, A.: Oceanic primary production: II. Estimation at global scale from satellite (Coastal Zone Color Scanner) chlorophyll, Global Biogeochem. Cy., 10, 57-69, 1996.

Basset, A., Sangiorgio, F., and Sabetta, L.: Nuovi approcci metodologici per la classificazione dello stato di qualità degli ecosistemi acquatici di transizione, Metodologie ISPRA, 109 pp., 2009.

Bosc, E., Bricaud, A., and Antoine, D.: Seasonal and interannual variability in algal biomass and primary production in the Mediterranean Sea, as derived from 4 years of SeaWiFS observations, Global Biogeochem. Cy., 18, 1-16, 2004.

Brewin, R. J. W., Sathyendranath, S., Hirata, T., Lavender, S. J., Barciela, R., and Hardman Mountford, N. J.: A three-component model of phytoplankton size class from satellite remote sensing, Ecol. Model., 221, 1472-1483, 2010.

Brewin, R. J. W., Hardman-Mountford, N. J., and Hirata, T.: Detecting phytoplankton community structure from ocean colour, in: Handbook of Satellite Remote Sensing Image Interpretation: Applications for Marine Living Resources Conservation and Management, edited by: Morales, J., Stuart, V., Platt, T., and Sathyendranath, S., EU PRESPO and IOCCG, Dartmouth, Canada, 125138, 2011a.

Brewin, R. J. W., Devred, E., Sathyendranath, S., Lavender, S. J., and Hardman-Mountford, N. J.: Model of phytoplankton absorption based on three size classes, Appl. Optics, 50, 4353-4364, 2011b.

Bricaud, A., Claustre, H., Ras, J., and Oubelkheir, K.: Natural variability of phytoplanktonic absorption in oceanic waters: Influence of the size structure of algal populations, J. Geophys. Res., 109, C11010, doi:10.1029/2004JC002419, 2004.

Brown, J. H., Gillooly, J. F., Allen, A. P., Savage, V. M., and West, G. B.: Toward a metabolic theory of ecology, Ecology, 85, 17711789, doi:10.1890/03-9000, 2004.

Cataletto, B., Cabrini, M., Del Negro, P., Giani, M., Monti, M., and Tirelli, V.: La rete italiana per la ricerca ecologica a lungo termine (LTER-Italia) situazione e prospettive dopo un quinquennio di attività (2006-2011), Bertoni R., Golfo di Trieste, 180$181,2012$.

Chisholm, S. W.: Phytoplankton size, in: Primary Productivity and Biogeochemical Cycles in the Sea, edited by: Falkowski, P. G. and Woodhead, A. D., Plenum Press, New York, USA, 213-237, 1992.

Claustre, H. and Maritorena, S.: The many shades of ocean blue, Science, 302, 1514-1515, 2003.

Claustre, H., Morel, A., Hooker, S. B., Babin, M., Antoine, D., Oubelkheir, K., Bricaud, A., Leblanc, K., Quéguiner, B., and Maritorena, S.: Is desert dust making olig- 
otrophic waters greener?, Geophys. Res. Lett., 29, 1-7, doi:10.1029/2001GL014506, 2002.

D'Alimonte, D. and Zibordi, G.: Phytoplankton Determination in an Optically Complex Coastal Region Using a Multilayer Perceptron Neural Network, IEEE Geosci. Remote S., 41, 2861-2868, 2003.

D'Alimonte, D., Mélin, F., Zibordi, G., and Berthon, J.-F.: Use of the novelty detection technique to identify the range of applicability of the empirical ocean color algorithms, IEEE T. Geosci. Remote, 41, 2833-2843, 2003.

D'Ortenzio, F. and Ribera d'Alcalà, M.: On the trophic regimes of the Mediterranean Sea: a satellite analysis, Biogeosciences, 6, 139-148, doi:10.5194/bg-6-139-2009, 2009.

D’Ortenzio, F., Marullo, S., Ragni, M., d'Alcala, M. R., and Santoleri, R.: Validation of empirical SeaWiFS algorithms for chlorophyll-alpha retrieval in the Mediterranean Sea - a case study for oligotrophic seas, Remote Sens. Environ., 82, 79-94, 2002.

Devred, E., Sathyendranath, S., Stuart, V., Maass, H., Ulloa, O., and Platt, T.: A two-component model of phytoplankton absorption in the open ocean: Theory and applications, J. Geophys. Res., 111, C03011, doi:10.1029/2005JC002880, 2006.

Di Cicco, A.: Spatial and temporal variability of dominant Phytoplankton Size Classes in the Mediterranean Sea from Remote Sensing, PhD thesis in Ecology and Management of Biological Resources, Tuscia University, 1-110, 2014.

Falkowski, P. G., Barber, R. T., and Smetacek, V.: Biogeochemical Controls and Feedbacks on Ocean Primary Production, Science, 281, 200-206, 1998.

Finkel, Z. V., Beardall, J., Flynn, K. J., Quigg, A., Rees, T. A. V., and Raven J. A.: Phytoplankton in a changing world: cell size and elemental stoichiometry, J. Plankton Res., 32, 119-137, 2010.

Fonda Umani, S., Milani, L., Borme, D., de Olazabal, A., Parlato, S., Precali, Kraus, R., Lučić, D., Njire, J., Totti, C., Romagnoli, T., Pompei, M., and Cangini, M.: Inter-annual variations of planktonic food webs in the northern Adriatic Sea, Sci. Total Environ., 353, 218-231, 2005.

Font, J., Puig, P., Salat, J., Palanques, A., and Emelianov, M.: Sequence of hydrographic changes in NW Mediterranean deep water due to the exceptional winter of 2005, Sci. Mar., 71, 339-346, 2007.

Fujiwara, A., Hirawake, T., Suzuki, K., and Saitoh, S.-I.: Remote sensing of size structure of phytoplankton communities using optical properties of the Chukchi and Bering Sea shelf region, Biogeosciences, 8, 3567-3580, doi:10.5194/bg-8-3567-2011, 2011.

Gieskes, W. W. C., Kraay, G. W., Nontji, A., and Setiapermana, D.: Monsoonal alternation of a mixed and a layered structure in the phytoplankton of the euphotic zone of the Banda Sea (Indonesia): A mathematical analysis of algal pigment fingerprints, Neth. J. Sea Res., 22, 123-137, 1988.

Gitelson, A., Karnieli, A., Goldman, N., Yacobi, Y., and Mayo, M.: Chlorophyll estimation in the Southeastern Mediterranean using CZCS images - adaptation of an algorithm and its validation, J. Marine Syst., 9, 283-290, 1996.

Hirata, T., Aiken, J., Hardman-Mountford, N., Smyth, T. J., and Barlow, R. G.: An absorption model to determine phytoplankton size classes from satellite ocean colour, Remote Sens. Environ., 112, 3153-3159, 2008.
Hirata, T., Hardman-Mountford, N. J., Brewin, R. J. W., Aiken, J., Barlow, R., Suzuki, K., Isada, T., Howell, E., Hashioka, T., Noguchi-Aita, M., and Yamanaka, Y.: Synoptic relationships between surface Chlorophyll- $a$ and diagnostic pigments specific to phytoplankton functional types, Biogeosciences, 8, 311-327, doi:10.5194/bg-8-311-2011, 2011.

Hooker, S., Heukelem, L., Thomas, C., Claustre, H., Ras, J., Barlow, R., Sessions, H., Schlüter, L., Perl, J., Trees, C., Suart, V., Head, E., Clemenston, L., Fishwick, J., Llewellyn, C., and Aiken, J.: The Second SeaWIFS HPLC Analysis Round-Robin Experiment (SeaHARRE-2) NASA/TM-2005-212785, 1-112, 2005.

Irwin, A. J., Finkel, Z. V., Schofield, O. M. E., and Falkowski, P. G.: Scaling-up from nutrient physiology to the size-structure of phytoplankton communities, J. Plankton Res., 28, 459-471, doi:10.1093/plankt/fbi148, 2006.

Klauschies, T., Bauer, B., Aberle-Malzahn, N., Sommer, U., and Gaedke, U.: Climate change effects on phytoplankton depend on cell size and food web structure, Mar. Biol., 159, 2455-2478, doi:10.1007/s00227-012-1904-y, 2012.

Kostadinov, T. S., Siegel, D. A., and Maritorena, S.: Retrieval of the particle size distribution from satellite ocean color observations, J. Geophys. Res., 114, C09015, doi:10.1029/2009JC005303, 2009.

Krom, M. D., Herut, B., and Mantoura, R. F. C.: Nutrient budget for the eastern Mediterranean: implications for phosphorus limitation, Limnol. Oceanogr., 49, 1582-1592, 2004.

Lacombe, H., Gascard, J. C., Gonella, J., and Bethoux, J. P.: Response of the Mediterranean to the water and energy fluxes across its surface, on seasonal and interannual scales, Oceanol. Acta, 4, 247-255, 1981.

Le Quéré, C., Harrison, S. P., Colin Prentice, I., Buitenhuis, E. T., Aumont, O., Bopp, L., Claustre, H., Cotrim Da Cunha, L., Geider, R., Giraud, X., Klaas, C., Kohfeld, K. E., Legendre, L., Manizza, M., Platt, T., Rivkin, R. B., Sathyendranath, S., Uitz, J., Watson, A. J., and Wolf-Gladrow, D.: Ecosystem dynamics based on plankton functional types for global ocean biogeochemistry models, Glob. Change Biol., 11, 2016-2040, 2005.

Lévy, M., Memery, L., and André, J. M.: Simulation of primary production and export fluxes in the Northwestern Mediterranean Sea, J. Mar. Res., 56, 197-238, 1998a.

Lévy, M., Memery, L., and Madec, G.: The onset of a bloom after deep winter convection in the northwestern Mediterranean Sea: mesoscale process study with a primitive equation model, J. Marine Syst., 16, 7-21, 1998 b.

Malej, A., Mozetic, P., Malacic, V., Terzic, S., and Ahel, M.: Phytoplankton responses to freshwater inputs in a small semi-enclosed gulf (Gulf of Trieste, Adriatic Sea), Mar. Ecol.-Prog. Ser., 120, 111-121, 1995.

Marañón, E., Cermeño, P., Latasa, M., Tadonléké Rémy, D.: Temperature, resources, and phytoplankton size structure in the ocean, Limnol. Oceanogr., 57, 1266-1278, doi:10.4319/lo.2012.57.5.1266, 2012.

Marty, J. C. and Chiaverini, J.: Seasonal and interannual variations in phytoplankton production at DYFAMED time-series station, northwestern Mediterranean Sea, Deep-Sea Res. Pt. II, 49, 2017 2030, 2002.

Marinov, I., Doney, S. C., and Lima, I. D.: Response of ocean phytoplankton community structure to climate change over the $21 \mathrm{st}$ century: partitioning the effects of nutrients, temperature and 
light, Biogeosciences, 7, 3941-3959, doi:10.5194/bg-7-39412010, 2010.

Mercado, J. M., Ramìrez, T., Cortès, D., Sebastiàn, M., and VargasYàñez, M.: Seasonal and inter-annual variability of the phytoplankton communities in an upwelling area of the Alborán Sea (SW Mediterranean Sea), Sci. Mar., 69, 451-465, 2005.

Moisan, T. A. H., Sathyendranath, S., and Bouman, H. A.: Ocean color remote sensing of the phytoplankton functional types, in: Remote Sensing of Biomass - Principles and Applications, edited by: Temilola Fatoyinbo, chapter 5, 101-122, 2012.

Morel, A. and Bricaud, A.: Theoretical results concerning lightabsorption in a discrete medium, and application to specific absorption of phytoplankton, Deep-Sea Res., Part A, 28, 13751393, 1981

Morel, A. and Gentili, B.: The dissolved yellow substance and the shades of blue in the Mediterranean Sea, Biogeosciences, 6 , 2625-2636, doi:10.5194/bg-6-2625-2009, 2009.

Mouw, C. B. and Yoder, J. A.: Optical determination of phytoplankton size composition from global SeaWiFS imagery, J. Geophys. Res., 115, C12018, doi:10.1029/2010JC006337, 2010.

Nair, A., Sathyendranath, S., Platt, T., Morales, J., Stuart, V., Forget, M. H., Devred, E., and Bouman, H.: Remote sensing of phytoplankton functional types, Remote Sens. Environ., 112, 33663375, 2008.

Navarro, G., Alvain, S., Vantrepotte, V., and Huertas, I. E.: Identification of dominant Phytoplankton Functional Types in the Mediterranean Sea based on a regionalized remote sensing approach, Remote Sens. Environ., 152, 557-575, 2014.

O'Reilly, J. E., Maritorena, S., Mitchell, B. G., Siegel, D. A., Carder, K. L., Garver, S. A., Kahru, M., and McClain, C.: Ocean chlorophyll algorithms for SeaWiFS, J. Geophys. Res., 103, 24937-24953, 1998.

Organelli, E., Nuccio, N., and Massi, L.: Individuazione dei principali gruppi fitoplanctonici in base al loro contributo di assorbimento e retrodiffusione nella riflettanza, Ecologia Limnologia e Oceanografia: quale futuro per l'ambiente, Ancona, 17-20 September 2007, S. It. E., 181-187, 2007.

Park, J.-Y., Kung, J.-S., Bader, J., Rolph, R., and Kwon, M.: Amplified Arctic warming by phytoplanknton under greenhouse warming, P. Natl. Acad. Sci. USA, 112, 1-6, doi:10.1073/pnas.1416884112, 2015.

Raven, J. A.: The twelfth Tansley Lecture. Small is beautiful: the picophytoplankton, Func. Ecol., 12, 503-513, doi:10.1046/j.13652435.1998.00233.x, 1998.

Reynolds, C. S.: Physical Determinants of Phytoplankton Succession, in: Plankton Ecology, edited by: Sommer, U., Brock/Springer Series in Contemporary Bioscience, Springer Berlin Heidelberg, 9-56, 1989.

Ribera d'Alcalà, M., Civitarese, G., Conversano, F., and Lavezza, R.: Nutrient fluxes and ratios hint at overlooked processes in the Mediterranean Sea, J. Geophys. Res., 108, 8106, doi:10.1029/2002JC001650, 2003

Robinson, A. R. and Golnaraghi, M.: The physical and dynamical oceanography of the Mediterranean Sea, in: Ocean Processes in Climate Dynamics: Global and Mediterranean Examples, edited by: Malanotte-Rizzoli, P. and Robinson, A. R., NATO-ASI, Kluwer Academic Publishers, Dordrecht, the Netherlands, 255306, 1994
Russo, A., Maccaferri, S., Djakovac, T., Precali, R., Degobbis, D., Deserti, M., Paschini, E., and Lyons, D. M.: Meteorological and oceanographic conditions in the northern Adriatic Sea during the period June 1999-July 2002: Influence on the mucilage phenomenon, Sci. Total Environ., 353, 24-38, 2005.

Sarhan, T., García-Lafuente, J., Vargas, M., Vargas, J. M., and Plaza, F.: Upwelling mechanisms in the northwestern Alboran Sea, J. Marine Syst., 23, 317-331, 2000.

Santoleri, R., Banzon, V., Marullo, S., Napolitano, E., D’Ortenzio, F., and Evans, R.: Year-to-year variability of the phytoplankton bloom in the southern Adriatic Sea (1998-2000): sea-viewing Wide Field-of-view Sensor observations and modeling study, J. Geophys. Res., 108, 1-23, 2003.

Santoleri, R., Volpe, G., Marullo, S., and Nardelli, B. B.: Open waters optical remote sensing of the Mediterranean Sea, Remote Sensing of the European Seas, Springer, 103-116, 2008.

Santinelli, C., Sempéré, R., Van Wambeke, F., Charriere, B., and Seritti, A.: Organic carbon dynamics in the Mediterranean Sea: an integrated study, Global Biogeochem. Cy., 26, GB4004, doi:10.1029/2011GB004151, 2012.

Sathyendranath, S. (Ed.): Phytoplankton Functional Types from Space. Reports of the International Ocean-Colour Coordinating Group, IOCCG. No. 15, IOCCG, Dartmouth, Canada, 1-135, 2014.

Sathyendranath, S., Stuart, V., Cota, G., Maas, H., and Platt, T.: Remote sensing of phytoplankton pigments: a comparison of empirical and theoretical approaches, Int. J. Remote Sens., 22, 249 273, 2001.

Sieburth, J. M., Smetacek, V., and Lenz, J.: Pelagic ecosystem structure: heterotrophic compartments of the plankton and their relationship to plankton size fractions, Limnol. Oceanogr., 23, 12561263, 1978.

Siokou-Frangou, I., Christaki, U., Mazzocchi, M. G., Montresor, M., Ribera d'Alcalá, M., Vaqué, D., and Zingone, A.: Plankton in the open Mediterranean Sea: a review, Biogeosciences, 7, 1543 1586, doi:10.5194/bg-7-1543-2010, 2010.

Smith, R. O., Bryden, H. L., and Stansfield, K.: Observations of new western Mediterranean deep water formation using Argo floats 2004-2006, Ocean Sci., 4, 133-149, doi:10.5194/os-4-133-2008, 2008.

Stravisi, F.: Le precipitazioni a Trieste (1787-2003), in: La variabilità del clima locale relazionata ai fenomeni di cambiamento globale, edited by: Cortemiglia, G. C., Pàtron, Bologna, 289325, 2006.

Struglia, M. V., Mariotti, A., and Filograsso, A.: River discharge into the Medtierranean Sea: climatology and aspects of the observed variability, J. Climate, 17, 4740-4751, 2004.

Thingstad, F. T. and Rassoulzadegan, F.: Conceptual models for the biogeochemical role of the photic zone microbial food web, with particular reference to the Mediterranean Sea, Prog. Oceanogr., 44, 271-286, 1999.

Timmermans, K. R., Van derWagt, B., Veldhuis, M. J. W., Maatman, A., and De Baar, H. J. W.: Physiological responses of three species of marine pico-phytoplankton to ammonium, phosphate, iron and light limitation, J. Sea Res., 53, 109-120, 2005.

Uitz, J., Claustre, H., Morel, A., and Hooker, S. B.: Vertical distribution of phytoplankton communities in open ocean, An assessment based on surface chlorophyll, J. Geophys. Res., 111, C08005, doi:10.1029/2005JC003207, 2006. 
Uitz, J., Claustre, H., Gentili, B., and Stramski, D.: Phytoplankton class-specific primary production in the world's oceans: seasonal and interannual variability from satellite observations, Global Biogeochem. Cy., 24, GB3016, doi:10.1029/2009GB003680, 2010.

Uitz, J., Stramski, D., Gentili, B., D’Ortenzio, F., and Claustre, H.: Estimates of phytoplankton class-specific and total primary production in the Mediterranean Sea from satellite ocean color observations, Global Biogeochem. Cy., 26, GB2024, doi:10.1029/2011gb004055, 2012.

Vidussi, F., Claustre, H., Manca, B. B., Luchetta, A., and Marty, J.: Phytoplankton pigment distribution in relation to upper thermocline circulation in the eastern Mediterranean Sea during winter, J. Geophys. Res., 106, 19939-19956, 2001.

Volpe, G., Santoleri, R., Vellucci, V., Ribera d'Alcalà, M., Marullo, S., and D'Ortenzio, F.: The colour of the Mediterranean Sea: global versus regional biooptical algorithms evaluation and implication for satellite chlorophyll estimates, Remote Sens. Environ., 107, 625-638, 2007.
Volpe, G., Colella, S., Forneris, V., Tronconi, C., and Santoleri, R.: The Mediterranean Ocean Colour Observing System - system development and product validation, Ocean Sci., 8, 869-883, doi:10.5194/os-8-869-2012, 2012a.

Volpe, G., Buongiorno Nardelli, B., Cipollini, P., Santoleri, R. S., and Robinson, I.: Seasonal to interannual phytoplankton response to physical processes in the Mediterranean Sea from satellite observations, Remote Sens. Environ., 117, 223-235, 2012 b.

Werdell, P. J. and Bailey, S. W.: An improved bio-optical data set for ocean color algorithm development and satellite data product validation, Remote Sens. Environ., 98, 122-140, 2005.

Zohary, T. and Robarts, R. D.: Experimental study of microbial P limitation in the eastern Mediterranean, Limnol. Oceanogr., 43, 387-395, 1998. 